NBER WORKING PAPER SERIES

\title{
THE INEFFICIENCY OF REFINANCING: WHY PREPAYMENT PENALTIES ARE GOOD FOR RISKY BORROWERS
}

\author{
Christopher J. Mayer \\ Tomasz Piskorski \\ Alexei Tchistyi \\ Working Paper 16586 \\ http://www.nber.org/papers/w16586
}

\author{
NATIONAL BUREAU OF ECONOMIC RESEARCH \\ 1050 Massachusetts Avenue \\ Cambridge, MA 02138 \\ December 2010
}

\begin{abstract}
This research was completed while Mayer was a Visiting Scholar at the Federal Reserve Board and the Federal Reserve Bank of New York. We thank Patrick Bolton, Bruce Carlin, Raj Chetty, Douglas Diamond, Scott Frame, Mark Garmaise, Mikhail Golosov, Daniel Hubbard, Randall Kroszner, David Laibson, Karen Pence, Mitch Peterson, Rafael Repullo, Tony Sanders, Shane Sherlund, Chester Spatt, Jeremy Stein, Suresh Sundaresan, Aleh Tsyvinski, Neng Wang, Matthew Weinzierl, and seminar participants at Columbia Business School, UC Berkeley, Harvard, Chicago Fed, UC Irvine, AEA Annual Meeting, NBER Corporate Finance meeting, NBER Housing and Public Policy meeting, Stanford Institute for Theoretical Economics meeting, AREUEA summer meeting, 3rd NYC Real Estate Meeting, University of Virginia Law School conference on "Law and Economics of Consumer Credit", SED meeting, Summer Real Estate Symposium, AREUEA annual meeting for helpful comments and suggestions. Adam Ashcraft, Andrew Haughwout, Andreas Lehnert, Karen Pence, and Joe Tracy provided invaluable help in putting together and understanding the data. Alex Chinco and Rembrandt Koning provided excellent research assistance and helpful modeling suggestions. The research was supported by the Paul Milstein Center for Real Estate at Columbia Business School. The comments are the opinions of the authors and do not represent the views of the Federal Reserve System or the National Bureau of Economic Research.
\end{abstract}

NBER working papers are circulated for discussion and comment purposes. They have not been peerreviewed or been subject to the review by the NBER Board of Directors that accompanies official NBER publications.

(C) 2010 by Christopher J. Mayer, Tomasz Piskorski, and Alexei Tchistyi. All rights reserved. Short sections of text, not to exceed two paragraphs, may be quoted without explicit permission provided that full credit, including $\odot$ notice, is given to the source. 
The Inefficiency of Refinancing: Why Prepayment Penalties Are Good for Risky Borrowers

Christopher J. Mayer, Tomasz Piskorski, and Alexei Tchistyi

NBER Working Paper No. 16586

December 2010

JEL No. D12,D14,D53,G14,G21,G28,R31,R38

\begin{abstract}
$\underline{\text { ABSTRACT }}$
This paper explores the practice of mortgage refinancing in a dynamic competitive lending model with risky borrowers and costly default. We show that prepayment penalties improve welfare by ensuring longer-term lending contracts, which prevents the mortgage pools from becoming disproportionately composed of the riskiest borrowers over time. Mortgages with prepayment penalties allow lenders to lower mortgage rates and extend credit to the least creditworthy, with the largest benefits going to the riskiest borrowers, who have the most incentive to refinance in response to positive credit shocks. Empirical evidence from more than 21,000 non-agency securitized fixed rate mortgages is consistent with the key predictions of our model. Our results suggest that regulations banning refinancing penalties might have the unintended consequence of restricting access to credit and raising rates for the least creditworthy borrowers.
\end{abstract}

Christopher J. Mayer

Columbia Business School

3022 Broadway, Uris Hall \#101

New York, NY 10027

and NBER

cm310@columbia.edu

Tomasz Piskorski

Graduate School of Business

Columbia University

3022 Broadway

Uris Hall 810

New York, NY 10027

tp2252@columbia.edu

\author{
Alexei Tchistyi \\ Haas School of Business \\ University of California, Berkeley \\ 545 Student Services Building \#1900 \\ Berkeley, CA 94720-1900 \\ tchistyi@haas.berkeley.edu
}




\section{Introduction}

Until recently, prepayment penalties were widely used in mortgages, particularly in loans given to the least creditworthy borrowers. As the housing market collapsed, prepayment penalty clauses created a storm of controversy and were blamed for the stunning increase in delinquencies and defaults among the riskiest residential borrowers. Critics contended that prepayment penalties hurt borrowers already saddled with high interest payments. They often point to a high concentration of prepayment penalties among less creditworthy borrowers as evidence of predatory lending, and accuse mortgage originators of abusing borrowers who do not fully understand mortgage terms.

In response to these concerns, legislators and regulators imposed new rules restricting the use of prepayment penalties. ${ }^{1}$ Despite the criticism and threats of regulation, mortgage originators have defended prepayment penalties as a way to ensure that they can make mortgages available for high risk borrowers.

Most empirical and theoretical work on mortgage refinancing focuses on savings associated with lower market interest rates. In this paper, we propose a second and economically important reason that borrowers refinance: lower rates due to the lower risk premium associated with positive credit shocks.

Our focus is motivated by data from the last decade showing that an appreciable number of refinancings appear unrelated to mortgage rate declines. According to the Freddie Mac Primary Mortgage Market Survey, in June, 2003, mortgage rates hit a local low of 5.23 percent and averaged 5.8 percent for the year. Rates remained relatively flat in 2004 and 2005 (averaging 5.84 and 5.87 percent, respectively), before rising to 6.41 percent in 2006. Yet refinancing activity was remarkably strong even in the face of flat or rising mortgage rates. According to data reported under the Home Mortgage Disclosure Act (HMDA), about 15 million mortgages were refinanced

\footnotetext{
${ }^{1}$ See, among others, the Board of Governors of the Federal Reserve System's final rule amending Regulation Z published in July 2008 and H.R. 1728: Mortgage Reform and Anti-Predatory Lending Act of 2009.
} 
in 2003 when mortgage rates hit their low. About 7 million mortgage refinancings were processed each year 2004 and 2005, and another 6 million mortgages were refinanced in $2006{ }^{2}$ Improvements in household credit during the economic boom and rising house prices (another source of positive household wealth shocks) are likely important contributors to these large numbers of refinancings. ${ }^{3}$

When considering improvements in credit (or positive wealth shocks) as an additional reason for refinancing mortgages, we argue that prepayment penalties serve an important role by helping to ensure that mortgage pools do not becoming disproportionately composed only with the riskiest borrowers over time. Enforcement of longer-term lending contracts allows the lenders to charge lower mortgage rates and to extend credit to the least creditworthy borrowers. This increases welfare, with the riskiest borrowers benefiting the most. The use of prepayment penalties to provide credit to risky borrowers is a market alternative to the government subsidizing credit to risky borrowers by cutting lending standards or allowing lower downpayments.

To formalize this argument, we develop a simple dynamic competitive lending model with fixed rate mortgage contracts (FRMs), but with no changes in aggregate interest rates. Within the model, we consider borrowers who differ only in their initial wealth (a measure of credit quality). Borrowers may choose to obtain a FRM to purchase a home. Homeownership is assumed to generate positive utility gains for the borrowers. Once a mortgage is originated, the borrower's creditworthiness evolves stochastically over time. When borrowers receive positive credit shocks, they would like to refinance to obtain a lower mortgage rate that is commensurate with their new lower default risk. Borrowers who receive severe enough negative financial shocks will default. Default is assumed to be costly, due to high foreclosure costs and other deadweight losses. Over time, the borrowers who choose to refinance are those whose creditworthiness has improved the

\footnotetext{
${ }^{2}$ Even in 2000, when mortgage rates hit a 15 -year high of 8.05 percent, more than 2.4 million refinancings were processed.

${ }^{3}$ Of course, some of these refinancings involved homeowners cashing out their home equity, not just those searching for lower mortgage rates due to positive credit shocks. Nevertheless, it is reasonable to expect that a sizeable number of households have cashed out their home equity following house appreciation. Thus, a substantial part of cash out refinancings might have been effectively induced by positive credit shocks.
} 
most. Thus, without restrictions on prepaying a loan, mortgage pools are increasingly composed of the least creditworthy borrowers; that is, borrowers who have received zero or negative credit shocks since mortgage origination.

Our model allows us to solve for the equilibrium mortgage interest rate. Of course, as in all credit models, the mortgage premium increases as observed credit quality falls. Higher mortgage premiums compensate the lender for larger expected losses due to increased defaults by riskier borrowers. However, our model also generates a second reason that lenders charge a higher mortgage premium for lending to risky borrowers. In the face of refinancing, a rational lender anticipates adverse selection in mortgage pools over time and will compensate for it by charging a higher premium on loans that are freely prepayable. The required lending premium to compensate for prepayment risk is highest for the riskiest borrowers, as these borrowers are the ones most likely to prepay if they receive a positive credit shock.

In our model, a prepayment penalty acts as a commitment device that allows the borrower to credibly remain with the same lender for a longer period of time. We show that this commitment is valuable as it allows the lender to use borrowers with good ex-post credit shocks to cross-subsidize borrowers with poor ex-post credit shocks.

Refinancing generates two types of inefficiencies, both of them due to the fact that lenders must charge ex-ante higher mortgage rates for fully prepayable mortgages. First, the higher ex-ante mortgage premium makes the ex-post less creditworthy borrowers (those who received negative financial shocks) more likely to default, which is socially costly. Second, the required increase in premium to compensate for refinancing leads some particularly high-risk borrowers to be excluded from the credit markets, although these borrowers would otherwise be able to qualify for a loan if refinancing were not allowed (e.g., if prepayment penalties were employed). Both of these effects reduce welfare. Therefore, we conclude that prepayment penalties can benefit borrowers, with the riskiest borrowers benefitting the most. 
Our result on the inefficiency of refinancing is similar in spirit to the observation that lack of consumer commitment can generate inefficiencies in life or health insurance markets. Short-term contracts do not offer insurance against "reclassification risk" ${ }^{4}$, so bad news about the persistent health status of a consumer can result in increased premiums. From an ex-ante perspective, commitment to a long-term contract can provide insurance against reclassification risk and thus be welfare-improving.

We examine the predictions of our model using data on securitized mortgages obtained from LoanPerformance, a subsidiary of First American CoreLogic, Inc. In order to match the model as closely as possible and to limit the likelihood of refinancing driven by lower aggregate interest rates, we generate a sample of more than 21,000 fixed rate mortgages originated in June 2003, when market interest rates were at their lowest point in over two decades. We also focus exclusively on FRMs to avoid empirical complications in those cases where borrowers choose to refinance in order to avoid an upward adjustment in mortgage rates when an initial teaser rate expires or when short-term interest rates rise.

The empirical work is consistent with the key predictions of our model. First, we examine prepayment behavior in FRMs without prepayment penalties in response to a house price shock (a proxy for an ex-post wealth shock). We find that borrowers who receive positive house price shocks are much more likely to prepay their mortgage than borrowers in locations where house prices grew less quickly. Moreover, the prepayment rate of the high risk (subprime) borrowers is much more sensitive to house price changes than the prepayment rate of low risk (prime) borrowers. In response to a one standard deviation increase in the rate of house price appreciation, subprime borrowers are about 12 percent more likely to prepay their mortgages. By contrast, relatively safe prime borrowers increase their likelihood of paying off their mortgage by only about 2 percent in response to the same one standard deviation increase in house price appreciation (with this effect

\footnotetext{
${ }^{4}$ Cochrane (1995) refers to "reclassification risk" as "premium risk". See also Hendel and Lizzeri (2003) for a recent application in the context of life insurance.
} 
being not statistically signifcant).

Next we examine the use of prepayment penalties. Consistent with our model, we show that the riskiest (subprime) borrowers are the most likely to have prepayment penalties, with about 72 percent of these loans having prepayment penalties. By comparison, less than 2 percent of prime borrowers have prepayment penalties.

Of course, many critics might argue that the riskiest borrowers are most susceptible to misunderstanding their mortgage and thus might unwittingly take on a loan with a prepayment penalty without any benefit. In contrast to that view, but consistent with our model, we find that among the group of less creditworthy borrowers, controlling for a number of observable risk characteristics, mortgages with prepayment penalties carry lower rates compared with loans with free refinancing, the more so the riskier the loans are. ${ }^{5}$ Subprime borrowers pay rates that are about 0.2 percentage points (or 20 basis points) lower when their loan has a prepayment penalty. We further divide these risky borrowers between those with a second lien (riskier loans) and those with a first lien (safer loans). The difference in mortgage rates when a second lien loan has a prepayment penalty is quite large (0.62 percent), while the difference for subprime borrowers among first lien mortgages is smaller (0.14 percent).

Our paper contributes to a sizeable real estate and finance literature that studies prepayment. The vast majority of this literature focuses on the changes in the market interest rate as the primary rationale for refinancing. ${ }^{6}$ Instead, we consider the changes in the borrower's creditworthiness as the reason for refinancing, and address the welfare consequences of prepayment penalties in a competitive equilibrium. In a related theoretical work, Dunn and Spatt (1985) show in a twoperiod setting that due-on-sale clauses can be optimal in a setting where the borrowers receive

\footnotetext{
${ }^{5}$ As we focus on 2003 originations we recognize that underwriting standards could have changed in the years just proceeding the crisis.

${ }^{6}$ See, among others, Findley and Capozza (1977), Dunn and McConnell (1981), Schwartz and Torous (1989), Stanton (1995), and Koijen, Van Hemert, and Van Nieuwerburgh, (2009). Kau, Keenan, Mueller, and Epperson (1992) and Deng, Quigley and Van Order (2000) consider changes in house prices as one of the factors affecting prepayment behavior.
} 
ex-post stochastic shocks to the incremental utility received from selling the house. Unlike their paper, our model features default, a change in the borrower's creditworthiness not related to moving out, and the possibility to sequentially refinance a mortgage while staying at the same house. We also investigate whether the model predictions are consistent with the data.

Our paper is also related to the life and health insurance literature showing that consumer commitment to a long-term contracts can provide insurance against reclassification risk and thus be welfare-improving (see, for example, Cochrane (1995) and Hendel and Lizzeri (2003)). ${ }^{7}$ Finally, our paper is also related to real estate and finance literature that addresses the implications of various constraints on the design of mortgages and the behavior of borrowers and lenders ${ }^{8}$, and to the recent empirical literature on subprime lending ${ }^{9}$ by examining the role of prepayment penalties in this market.

The paper is organized as follows. Section 2 presents the continuous-time setting of the model. Section 3 discusses competitive mortgage lending with FRM contracts with sufficiently high prepayment penalties to discourage refinancing. Section 4 studies the effect of refinancing on mortgage lending. Section 5 provides a computed example, while Section 6 discusses model extensions. Section 7 presents the empirical evidence. Section 8 concludes.

\footnotetext{
${ }^{7}$ See also Peterson and Rajan (1995) who show that exclusive relationship resulting from monopolistic lending makes creditors more likely to finance credit-constrained firms because it is easier for these creditors to internalize the benefits of assisting the firms.

${ }^{8}$ See, among others, Chari and Jagannathan (1989), Dunn and Spatt (1985), LeRoy (1996), Stanton and Wallace (1998), Spiegel and Strange (1992), Spiegel (2001), Deng, Quigley and Van Order (2000), Cocco (2004), Campbell and Cocco (2003, 2007), Lustig and Van Nieuwerburgh (2005), Ortalo-Magné and Rady (2006), Piskorski and Tchistyi (2010a, b).

${ }^{9}$ See, among others, Demyanyk and Van Hemert (2008), Mayer, Pence and Sherlund (2009), Mian and Sufi (2009, 2010), Keys, Mukherjee, Seru, and Vig (2010), Rajan, Seru, and Vig (2010), Piskorski, Seru, and Vig (2010))
} 


\section{Setup}

A borrower (a household) wants to buy a home at date $t=0 .{ }^{10}$ Home ownership delivers to the borrower a public and deterministic utility stream $\theta$. We assume that this utility stream remains constant as long as the borrower stays in the same house. ${ }^{11}$ The price of the home $P$ is greater than the borrower's initial wealth $S_{0} \cdot{ }^{12}$ Thus, the borrower must obtain funds from the lender to finance the house purchase. We assume that the borrower and the lender are sufficiently small that their actions have no effect on house prices. ${ }^{13}$

Each of the lenders is risk neutral, has unlimited capital, and values a stochastic cumulative cash flow $\left\{f_{t}\right\}$ as

$$
E\left[\int_{0}^{\infty} e^{-r t} d f_{t}\right]
$$

where $r$ is the market interest rate at which the lender discounts cash flows.

A borrower values a stochastic cumulative consumption flow $\left\{C_{t}\right\}$ as

$$
E\left[\int_{0}^{\infty} e^{-\gamma t} d C_{t}\right]
$$

where $d C_{t} \geq 0$. We assume that the borrower is more impatient than the lender, i.e., $\gamma>r_{t}$ for all $t$, reflecting that the intertemporal marginal rate of substitution for a borrowing-constrained household is greater then those of a financial institution in our setting. The borrower's consumption at $t, d C_{t} \geq 0$, represents the discretionary consumption of goods and services, which, among many

\footnotetext{
${ }^{10}$ To justify the initial purchase of the home, we assume that the borrower extracts more utility from the house when he owns it than when he rents it.

${ }^{11}$ For simplicity, we do not consider the possibility that the borrower can make adjustments that either increase or decrease the quality of the house. See Spiegel and Strange (1992), Shiller and Weiss (2000) and Spiegel (2001) who study the implications of such possibility.

${ }^{12}$ It is reasonable to expect that the home price $P$ is increasing in its utility $\theta$, and the borrower optimizes over the set of available $(\theta, P)$ pairs. This optimization is not considered in the paper, however this does not lead to a loss of generality, since our analysis applies to any $(\theta, P)$ pair.

${ }^{13}$ In a general equilibrium framework, actions of mortgage lenders and homebuyers on the aggregate level can affect macroeconomic variables. However, as long as the economic agents on the individual level have no market power, they should regard macroeconomic variables as exogenous in equilibrium.
} 
other things, may include such items as restaurant dining, vacation trips, buying a new car, et cetera. A consumption level of zero $\left(d C_{t}=0\right)$ means that the borrower consumes only goods and services that have priority over debt repayment, which can include items such as food, medicine, transportation, and other goods and services essential for the household.

A borrower must use his income to first cover the necessary expenses $\eta_{t}$ before spending on discretionary consumption or debt repayment. Let $\bar{Y}_{t} \geq 0$ denote the borrower's total cumulative income up to time $t$. We will focus on the borrower's "excess" cumulative income, $Y_{t} \equiv \bar{Y}_{t}-$ $\eta_{t}$, where $\left\{\eta_{t}\right\}$ is a cumulative level of necessary consumption given by an exogenous stochastic spending process that incorporates shocks such as medical bills, auto repair costs, fluctuations of food and gasoline prices, and so on. ${ }^{14}$ Therefore, the borrower's "excess" income $Y_{t}$ represents a better measure of the borrower's ability to pay for a house than his total income. From now on we will refer to $Y_{t}$ simply as the borrower's income.

We assume that a standard Brownian motion $Z=\left\{Z_{t} ; 0 \leq t<\infty\right\}$ drives the borrower's income process. Accordingly, the borrower's "excess" income up to time $t$, denoted by $Y_{t}$, evolves as

$$
d Y_{t}=\mu d t+\sigma d Z_{t}
$$

where $\mu \geq \theta$ is the drift of the borrower's "excess" income, and $\sigma$ is the sensitivity of the borrower's income to its Brownian motion component. We assume that the lender knows $\mu$ and $\sigma$, but does not know the realizations of the borrower's excess income shocks $Z_{t}$. Thus, realizations of the borrower's income are not contractible. These assumptions are motivated by the observation that lenders use a variety of methods ${ }^{15}$ to determine the type of the borrower (represented here by $(\mu, \sigma)$ pair) before the loan is approved, but henceforth do not condition the terms of the contract

\footnotetext{
${ }^{14}$ This specification of preferences has been used by Piskorski and Tchistyi $(2010 \mathrm{a}$, b) and is similar in flavor to the one used by Ait-Sahalia, Parker and Yogo (2004) who propose a partial resolution of the equity premium puzzle by distinguishing between the consumption of basic goods and that of luxury goods.

${ }^{15}$ Like credit score, demographic variables and so on.
} 
on the realizations of the borrower's income, likely because it is costly or impossible to monitor the borrower's necessary spending shocks and his total income.

The borrower maintains a savings account. The savings account balance $S$ grows at the interest rate $r$. The borrower must maintain a non-negative balance in his account.

Before the house purchase, the borrower and the lender sign a contract that will govern their relationship after the purchase is made. We assume that the borrower's and lender's actions have no effect on macroeconomic variables such as the market interest rate. ${ }^{16}$

In case of a mortgage foreclosure at time $\tau$, the borrower receives the value of his outside option, $A$, which represents the borrower's continuation utility after the loss of the home plus the value of any savings he might have at the time of default. The value $A$ incorporates such factors as the consumption value $\frac{\mu}{\gamma}$ of the borrower's expected future income, financial and intangible moving costs, losses with the damaged credit history, and the option to buy or rent another home in the future. The lender sells the repossessed house at a foreclosure auction and receives a payoff of $L$. We assume that $L<P \leq \frac{\theta}{r}$ and $A \leq \frac{\mu}{\gamma}$, which makes the liquidation inefficient, and that $P-L \geq \gamma\left(\frac{\theta}{r}-L\right)$, which insures that the default costs are not very small.

The borrower with initial wealth $S_{0}$ will decide to buy a house whenever the total utility he gets from homeownership is at least as big as the value $R\left(S_{0}\right)$ he could get by not buying. The value $R\left(S_{0}\right)$ represents the continuation utility of the borrower with initial wealth $S_{0}$ who does not to purchase a house. $R\left(S_{0}\right)$ incorporates such factors as the consumption value $(\mu / \gamma)$ of his expected future income, the value of savings $S_{0}$, and the option to buy or rent another home in the future. We assume that $R\left(S_{0}\right) \geq(\mu / \gamma)+S_{0}$, which implies that the outside value of a prospective borrower who does not purchase a house is at least as big as the sum of his initial wealth and the expected value of his "excess" disposable income.

\footnotetext{
${ }^{16}$ In a general equilibrium framework, actions of mortgage lenders and homebuyers in the aggregate can affect macroeconomic variables. However, as long as the individual economic agents have no market power, they should regard macroeconomic variables as exogenous in an equilibrium.
} 


\section{Fixed rate mortgage with no refinancing}

Before the purchasing a house, the borrower and the lender sign an exclusive contract that governs their relationship after the purchase is made. A sufficiently high prepayment penalty acts as a commitment device to ensure an exclusive relationship between the borrower and the lender until the borrower defaults.

We assume that under the terms of the fixed-rate mortgage the borrower is required to make

payments at the constant rate $\bar{\phi}$. If a contract is signed, the lender transfers the funds $P$ needed to purchase a home to the borrower at time 0 . Once the mortgage is originated, if the borrower fails to make the payment, a foreclosure is initiated and the borrower gets the value $A$ and the lender gets the value $L$.

The borrower's total expected payoff from the mortgage with no refinancing at time zero is given by

$$
\bar{U}_{0}=E\left[\int_{0}^{\tau} e^{-\gamma s}\left(\theta d t+d C_{t}\right)+e^{-\gamma \tau} A\right]
$$

where $\tau$ is the time when the borrower defaults on the mortgage. The lender's total discounted expected payments from the mortgage as of time zero are given by

$$
\bar{V}_{0}=E\left[\int_{0}^{\tau} e^{-r s} \bar{\phi} d t+e^{-r \tau} L\right]
$$

The borrower with initial wealth $S_{0}$ will decide to buy a house whenever the total utility he gets under homeownership is at least as big as the value $R\left(S_{0}\right)$ he could get by not buying, where $R\left(S_{0}\right) \geq \frac{\mu}{\gamma}+S_{0} \geq A+S_{0}$. Given this, a net utility gain for the borrower from homeownership financed by the FRM with coupon $\bar{\phi}$ and no refinancing allowed is bounded from above by $\int_{0}^{\tau} e^{-\gamma t}(\theta-\bar{\phi}) d t$. This implies the following lemma.

Lemma 1 Any coupon payment $\bar{\phi}$ in the FRM contract with no refinancing taken by the borrower 
satisfies $\bar{\phi} \leq \theta$.

Proof Directly follows from the above discussion.

Since the borrower's income is stochastic while the mortgage payments are fixed, the borrower will need to save part of his income in order to be able to make mortgage payments in the future. Thus, for a given fixed-rate mortgage, the borrower's continuation payoff $\bar{U}\left(S_{t}, \bar{\phi}\right)$ is a function of the mortgage payments $\bar{\phi}$ and balance $S_{t}$ on the borrower's savings account. The borrower's savings evolve according to

$$
d S_{t}=r S_{t} d t+d Y_{t}-\bar{\phi} d t-d C_{t}
$$

The borrower chooses his consumption and savings strategy $(C, S)$ to maximize his payoff given the mortgage contract. The borrower will save only if $\bar{U}^{\prime}\left(S_{t}, \bar{\phi}\right) \geq 1$, and consume only if $\bar{U}^{\prime}\left(S_{t}, \bar{\phi}\right) \leq 1$, where prime denotes the derivative with respect to $S$. This implies existence of an upper bound $S^{1}(\bar{\phi})$ on the amount the borrower will save. The following proposition formalizes this finding.

Proposition 1 For a given fixed-rate mortgage $\bar{\phi} \leq \theta$, the borrower's continuation payoff $\bar{U}\left(S_{t}, \bar{\phi}\right)$ and the maximum saving level $S^{1}(\bar{\phi})$ solve the following problem

$$
\begin{aligned}
\gamma \bar{U}(S, \bar{\phi}) & =\theta+(r S+\mu-\bar{\phi}) \bar{U}^{\prime}(S, \bar{\phi})+\frac{1}{2} \sigma^{2} \bar{U}^{\prime \prime}(S, \bar{\phi}) \text { for } S \in\left[0, S^{1}(\bar{\phi})\right] \\
\bar{U}(0, \bar{\phi}) & =A \\
\bar{U}^{\prime}(S, \bar{\phi}) & =1 \text { for } S \geq S^{1}(\bar{\phi}), \\
\bar{U}^{\prime \prime}(S, \bar{\phi}) & =0 \text { for } S \geq S^{1}(\bar{\phi}) .
\end{aligned}
$$

Function $\bar{U}\left(S_{t}, \bar{\phi}\right)$ is concave in $S$ and satisfies $\bar{U}^{\prime}(S, \bar{\phi})>1$ for $S \in\left(0, S^{1}(\bar{\phi})\right)$. The optimal strategy for the borrower is to consume only necessities when $S_{t} \in\left[0, S^{1}(\bar{\phi})\right]$, and to consume $S_{t}-S^{1}(\bar{\phi})$ immediately when $S_{t}>S^{1}(\bar{\phi})$. 
Proof In the Appendix.

Lemma 2 The borrower's continuation payoff $\bar{U}(S, \bar{\phi})$ is decreasing in the repayment rate $\bar{\phi}$.

Proof We remember that $\bar{U}(S, \bar{\phi})$ represents the total utility the borrower with initial savings of $S$ gets from the mortgage with a coupon payment of $\bar{\phi}$. Therefore, the more the borrower is asked to pay, the lower will be her utility under the FRM contract.

Given a choice of $\bar{\phi}$, the lender's total expected payments from the FRM mortgage with no refinancing allowed given to a borrower with initial wealth (savings) of $S_{0}$, as of time 0 , are equal to

$$
\begin{aligned}
V_{0}\left(S_{0}, \bar{\phi}\right) & =E\left[\int_{0}^{\tau\left(S_{0}, \bar{\phi}\right)} e^{-r t} \bar{\phi} d t+e^{-r \tau\left(S_{0}, \bar{\phi}\right)} L \mid \mathcal{F}_{0}\right] \\
& =\frac{\bar{\phi}}{r}-E\left[e^{-r \tau\left(S_{0}, \bar{\phi}\right)}\left(\frac{\bar{\phi}}{r}-L\right) \mid \mathcal{F}_{0}\right]
\end{aligned}
$$

In the above $\tau\left(S_{0}, \bar{\phi}\right)$ is the default time of the borrower implied by his optimal choice of consumption and savings characterized in Proposition 1, given his initial wealth $S_{0}$ and the required mortgage payments of $\bar{\phi}$.

We assume that the lending market is competitive. Therefore, given Lemma 2, the lender chooses the smallest $\bar{\phi}$ so that he breaks even. This leads us to the following definition.

Definition 1 The competitive mortgage repayment rate on the FRM with no refinancing for the borrower with initial level of wealth (savings) $S_{0}$ satisfies

$$
\bar{\phi}^{*}\left(S_{0}\right)=\left\{\inf \bar{\phi} \geq 0: V_{0}\left(S_{0}, \bar{\phi}\right)=P\right\}
$$


and the implied mortgage premium is given by

$$
\rho^{*}\left(S_{0}\right)=\frac{\bar{\phi}^{*}\left(S_{0}\right)}{P}-r
$$

The borrower takes the loan whenever

$$
\bar{U}\left(S_{0}, \bar{\phi}^{*}\left(S_{0}\right)\right) \geq R\left(S_{0}\right)
$$

Let $\underline{S}$ be the minimum level of wealth such that the borrower takes the loan and the lender breaks even. Let $\bar{S}$ be the initial level of wealth corresponding to the lowest coupon payment $\bar{\phi}^{*}$.

Proposition 2 The competitive mortgage repayment rate on the FRM with no refinancing, $\bar{\phi}^{*}$, is strictly decreasing in the borrower's initial savings on $[\underline{S}, \bar{S}]$. Moreover

$$
\bar{S}=\inf _{S \geq \underline{S}}\left\{S^{1}\left(\bar{\phi}^{*}(S)\right)\right\}
$$

\section{Proof In the Appendix.}

The above proposition is intuitive. The mortgage premium compensates the lender for the loss due to default. The lower the initial wealth (savings) of the borrower, the higher the probability of his default (the lower is the borrower's creditworthiness), and the larger the premium charged on the loan. In the above proposition $\bar{S}$ represents the wealth level of the most creditworthy borrower who obtains the lowest possible mortgage rate $\bar{\phi}^{*}(\bar{S})$.

\section{Fixed rate mortgage with refinancing}

In this section, we allow for refinancing of mortgage loans. Each time his creditworthiness sufficiently improves, the borrower can refinance the loan, i.e., replace the existing loan with a new 
loan of the same amount, but with a lower coupon payment. The borrower sticks to the existing loan when his creditworthiness deteriorates, as then refinancing would imply a higher interest rate premium on the mortgage and thus would make him worse-off.

The borrower's creditworthiness reflects the chances of default on the mortgage. We assume that the borrower has no debt other than the mortgage itself. Thus, given the borrower's type and a mortgage coupon of $\phi$, the borrower's creditworthiness increases in his saving level $S$, which evolves according to

$$
d S_{t}=r S_{t} d t+\mu d t+\sigma d Z_{t}-\phi d t-d C_{t}
$$

The borrower can refinance the loan when his creditworthiness improves by a certain amount ${ }^{17}$. This is represented by an increasing sequence of savings cutoffs $\left\{S^{i}\right\}_{i=1}^{K}$, where $S^{i}=0$ and $S^{K}=\bar{S}$, where $\bar{S}$ is defined in Proposition 2. The borrower refinances each time his saving level reaches the next cutoff point. The number of relevant cutoff points for the borrower with initial wealth level of $S_{0}$ is given by

$$
N_{S_{0}}=\#\left\{S>S_{0}: S \in\left\{S^{i}\right\}_{i=1}^{K}\right\}
$$

Define a sequence $\left\{S_{S_{0}}^{n}\right\}_{n=0}^{N_{S_{0}}}$ as

$$
\begin{aligned}
S_{S_{0}}^{0} & =S_{0}, \text { and if } N_{S_{0}}>0: \\
\left\{S_{S_{0}}^{n}\right\} & =\min \left\{S>S_{S_{0}}^{n-1}: S \in\left\{S^{i}\right\}_{i=1}^{K}\right\}, \text { for } n=1, \ldots, N_{S_{0}} .
\end{aligned}
$$

Then the borrower with initial wealth $S_{0}$ refinances for the $n$th time when his wealth reaches $S_{S_{0}}^{n}$.

Proposition 3 Let $S_{0}$ be an initial wealth of the borrower.

(i) If $S_{0} \geq \bar{S}$, the borrower's continuation payoff and the mortgage coupon under FRM with refinancing and competitive lending are equal to those with no refinancing.

\footnotetext{
${ }^{17}$ This assumption is justified by a discrete nature of the credit scoring technology and some potential refinancing costs the borrower has to bear.
} 
(ii) If $S_{0}<\bar{S}$ then $N_{S_{0}}>0$. Under the competitive lending market it is optimal for the borrower to refinance the loan each time his wealth reaches the next wealth level $\left\{S_{S_{0}}^{n}\right\}_{n=1}^{N_{S_{0}}}$. The borrower's continuation payoff after the nth refinancing, $U^{n}\left(S, \phi^{n}\right)$ for $n=0, \ldots, N_{S_{0}}$, is given by a concave twice continuously differentiable function that solves for $n=0, \ldots, N-1$ :

$$
\begin{aligned}
\gamma U^{n}\left(S, \phi^{n}\right) & =\theta+\left(r S+\mu-\phi^{n}\right)\left(U^{n}\right)^{\prime}\left(S, \phi^{n}\right)+\frac{1}{2} \sigma^{2}\left(U^{n}\right)^{\prime \prime}\left(S, \phi^{n}\right) \text { for } S \in\left[0, S_{S_{0}}^{n+1}\right], \\
U^{n}\left(0, \phi^{n}\right) & =A, \\
U^{n}\left(S_{S_{0}}^{n}, \phi^{n}\right) & =U^{n+1}\left(S_{S_{0}}^{n}, \phi^{n+1}\right),
\end{aligned}
$$

and $U^{N_{S_{0}}}\left(S, \phi^{N_{S_{0}}}\right)=\bar{U}\left(S, \phi^{N_{S_{0}}}\right)$ for all $S \geq 0$.

The corresponding market value of the mortgage with refinancing and the coupon $\phi^{n}$ solves:

$$
\begin{aligned}
r V^{n}\left(S, \phi^{n}\right) & =\phi^{n}+\left(r S+\mu-\phi^{n}\right)\left(V^{n}\right)^{\prime}\left(S, \phi^{n}\right)+\frac{1}{2} \sigma^{2}\left(V^{n}\right)^{\prime \prime}\left(S, \phi^{n}\right) \text { for } S \in\left[0, S_{S_{0}}^{n+1}\right], \\
V^{n}\left(0, \phi^{n}\right) & =L, \\
V^{n}\left(S_{S_{0}}^{n}, \phi^{n}\right) & =P,
\end{aligned}
$$

The competitive market coupon payments $\left\{\phi^{n}\right\}_{n=0}^{N}$ are given by

$$
\begin{aligned}
\phi^{n} & =\left\{\inf \phi \geq 0: V^{n}\left(S_{S_{0}}^{n}, \phi\right)=P\right\}, \text { for } n=0, \ldots, N_{S_{0}}-1 \\
\phi^{N_{S_{0}}} & =\bar{\phi}^{*}(\bar{S}) .
\end{aligned}
$$

The borrower takes the loan whenever $U^{0}\left(S_{0}, \phi^{0}\right) \geq R\left(S_{0}\right)$.

Due to its complexity, problem (7)-(14) does not allow for an analytical solution. We proceed with numerical computations to compare the fixed rate mortgage contract with refinancing to the fixed rate mortgage contract of the same amount with no refinancing. The following property is 
satisfied for a very large range of parameters that we tried in our computations. We have not been able to discover a counterexample that would not satisfy this property.

Property 1 Let $\underline{S}^{\text {ref }}$ be the minimum wealth (savings) of the borrower such that the borrower takes the FRM loan with refinancing and the lender breaks even. Then for $S_{0} \in\left[\underline{S}^{\text {ref }}, \bar{S}\right]$ the expected utility for the borrower under competitive lending is greater when refinancing is not allowed (e.g., in a regime with prepayment penalties):

$$
\bar{U}\left(S_{0}, \bar{\phi}^{*}\left(S_{0}\right)\right)>U^{0}\left(S_{0}, \phi^{0}\left(S_{0}\right)\right)
$$

and more so for riskier borrowers:

$$
\frac{d\left(\bar{U}\left(S_{0}, \bar{\phi}^{*}\left(S_{0}\right)\right)-U^{0}\left(S_{0}, \phi^{0}\left(S_{0}\right)\right)\right)}{d S_{0}}<0
$$

Mortgage premia are lower when refinancing is not allowed:

$$
\bar{\phi}^{*}\left(S_{0}\right)<\phi^{0}\left(S_{0}\right)
$$

and more so for riskier borrowers:

$$
\frac{d\left(\bar{\phi}^{*}\left(S_{0}\right)-\phi^{0}\left(S_{0}\right)\right)}{d S_{0}}<0
$$

Moreover, allowing for refinancing leads to an exclusion from the lending market of riskier borrowers:

$$
\underline{S}^{r e f}>\underline{S}
$$

The above property states that borrowers are worse off under the FRM contract when refinancing is allowed. Moreover, the worse is a borrower's creditworthiness (their initial wealth), the 
larger is the loss with refinancing. Allowing refinancing leads to higher initial mortgage premia. The differences in mortgage premia are higher for riskier borrowers. Allowing mortgage refinancing also causes some risky borrowers to be unable to obtain credit compared to the contracts with no refinancing . As homeownership is assumed to generate positive utility gains for borrowers, this exclusion from credit leads to lower utility for those who would otherwise qualify for credit without refinancing. Consequently, allowing a prepayment penalty is Pareto improving in this environment.

To illustrate this point consider a group of ex-ante identical borrowers obtaining FRM loans to purchase identical homes. Suppose that their initial wealth level (initial creditworthiness) is such that they would qualify for loan under both regimes (with and without refinancing allowed). As the borrowers are ex-ante identical, they will be charged the same premia on their loans. We recall that the mortgage premium compensates the lender for the expected losses due to defaults. Under the FRM contract without a prepayment penalty, those borrowers who become more creditworthy over time would refinance to obtain cheaper premia on their loans, leaving the less creditworthy behind. The rational lender would anticipate and compensate for this by charging a uniformly higher premium on the loans compared to the contract with prepayment penalty.

At first one could think that allowing for refinancing is welfare-neutral for those borrowers who would qualify for credit under both regimes. On one hand, ex-post less creditworthy borrowers (those who received bad shocks to their financial position) would be worse off compared to the contract with a prepayment penalty, as they would have to pay a higher premium. On the other hand, those borrowers whose creditworthiness would sufficiently improve ex-post (those who received positive shocks to their financial position) would refinance to lower premia and thus be better off compared to the contract with a prepayment penalty.

Property 1 states that these expected gains if the borrower's creditworthiness improves are not 
sufficient to offset the expected losses when the borrower's creditworthiness deteriorates. ${ }^{18}$ Why is it so? Charging a higher premium makes borrowers more likely to default, and the likelihood of default is more sensitive to premia for those who are less creditworthy. Consequently, the decrease in the likelihood of default due to lower premia of those who refinance is not sufficient to offset an increase in the likelihood of default due to higher premia paid by those whose creditworthiness deteriorates ex-post so that they cannot refinance. As a result, a possibility to refinance increases the expected number of defaults in a given pool of the borrowers. While lenders break even, by definition, defaults are costly for borrowers who are paying higher mortgage premia and are unable to get the utility advantage from remaining a homeowner after they default. Thus the greater number of defaults in a pool of mortgages with prepayment leads to an additional welfare loss relative to a pool of mortgages that do not allow prepayment.

A sufficiently high prepayment penalty allows the borrowers to credibly commit to staying with the same lender. As a result, lenders can charge lower premia due to the potential to cross subsidize. This cross-subsidization effectively provides a partial insurance; ex-post more creditworthy borrowers end up subsidizing those whose creditworthiness has deteriorated. This lowers the overall likelihood of socially costly default. Consequently, a prepayment penalty is Pareto improving in this environment.

\section{A numerical example}

In this section we illustrate the features of the competitive FRM mortgage lending with and without refinancing in a parametrized example. Table 1 shows the parameters of the model. The refinancing wealth cutoffs are set as $\left\{S^{i}\right\}_{i=1}^{K-1}=\{0.02 i\}_{i=1}^{K-1}$, with $S^{K}=\bar{S}=0.33$.

The left-hand side of Figure 1 shows the FRM mortgage premia under a competitive lending

\footnotetext{
${ }^{18}$ Property 1 is similar in spirit to the finding of Manso, Strulovici and Tchistyi (2010), who show that performancesensitive debt (PSD), the class of debt obligations whose interest payments depend on the borrower's performance, is inefficient compared to fixed-rate debt of the same market value.
} 
market without refinancing and with refinancing allowed as a function of the borrower's creditworthiness (initial wealth level). As before, no refinancing is justified by the imposition of a sufficiently high prepayment penalty.

Note that the borrower's credit score increases in his wealth level $S$ (the likelihood of default decreases with the wealth level). The vertical lines show the wealth cutoffs below the borrower does not qualify for a loan. We observe that mortgage premia are always decreasing in the wealth level, reflecting a lower likelihood of loss due to default whether or not refinancing is allowed. The mortgage premia with refinancing are larger compared to those without refinancing, and more so for riskier borrowers (with lower wealth levels).

We also observe that allowing for refinancing leads to a significant exclusion from the lending market of riskier types (those with lower wealth levels). Interestingly, it is the lender's participation constraint that dictates the exclusion from credit. In the regime with refinancing, the riskiest borrowers served (those with initial wealth of $\underline{S}^{\text {ref }}$ ) have a large net positive utility gain from homeownership. However, lenders cannot break even on those potential borrowers with low enough wealth, because higher mortgage premium is more than offset by costs associated with a higher likelihood of default.

The right-hand side of Figure 1 shows the borrower's net utility gain from homeownership financed by the FRM mortgage without and with refinancing allowed as a function of the borrower's initial wealth level. We observe that the borrower's net utility gain is lower when refinancing is allowed, more so for riskier borrowers. However, a large efficiency loss from refinancing in this example comes from the exclusion of riskier types who cannot enjoy the benefits of homeownership. Note that one could see more high cost (high premium) loans and more defaults if prepayment penalties are used, just because more risky borrowers would be able to qualify for a loan. 


\section{Extensions}

In this section, we discuss possible extensions of our model. We argue that, even if we take into account these additional factors, the main finding of the model still holds: prepayment penalties do provide benefits to the borrowers.

This observation is based on the following argument. In order to break even, the lender has to make money on the borrowers who receive positive wealth shocks, since the lender is likely to lose money on the borrowers who receive negative wealth shocks. However, in the absence of prepayment penalties, the lender's ability to make profit is more limited, since the borrowers with improved creditworthiness are able to refinance their mortgages and get lower mortgage premia. Hence, the lender has to either charge higher mortgage premia on mortgages without prepayment penalties, or avoid serving risky borrowers at all. We maintain that the same argument is valid in more general settings discussed below.

\subsection{Stochastic House Prices}

So far we have considered a time-homogeneous setting in which agents are infinitely lived and the borrower's average income and the liquidation and reservation values do not change over time. In a stochastic house price environment, an increase in house price would increase the borrower's creditworthiness (due to an increase in the value of collateral and his total wealth) and thus provide an additional incentive to refinance if this option is allowed. Similarly a decline in house price would lower the borrower's creditworthiness and could lead to a strategic default: the borrower may default even when he is still able to make mortgage payments.

Therefore, our argument supporting refinancing penalties would be stronger in a stochastic house price environment due to an additional source of variation in ex-post credit quality of the borrowers. In fact, in our empirical work we will use house price shocks as a proxy for ex-post wealth shocks. 


\subsection{Endogenous Refinancing Grid}

For simplicity, we assumed that refinancing happens on the exogenously determined refinancing grid. A more realistic assumption is that refinancing happens whenever it improves the borrower's utility by a certain amount (due, for example, to some associated transactions costs). This would endogenously determine a refinancing grid. Since our results hold for any grid, this does not change the predictions of our model. However, it generates a new prediction. Since the benefits of refinancing are higher for riskier borrowers, these borrowers are going to refinance their mortgages more often in response to positive wealth shocks. We test this prediction using house price shocks as a proxy for ex-post wealth shocks.

\subsection{Mobility motive to prepay}

The findings in our model are predicated on the assumption that borrowers have no reason to prepay their mortgage except to receive a lower mortgage premium. Of course, this analysis ignores other likely reasons that borrowers prepay mortgages, such as lower interest rates or the sale of a house to move to another location. Such moves may take place for employment or family reasons. Either way, borrowers who are likely to move receive a countervailing benefit of avoiding prepayment penalties that is not in our model. What would appear in our model to be an inefficient prepayment might instead be an efficiency enhancing move. Prepayment penalties that restrict mobility might well have a negative welfare effect. ${ }^{19}$

It is straightforward to incorporate some costs of prepayment penalties due to restricted mobility in our model. For the highest credit quality borrowers, the benefit of a prepayment penalty in terms of a lower rate premium is minimal. These borrowers already receive the lowest available mortgage rate, so even a small benefit of moving is likely enough to tip them in favor of choosing

\footnotetext{
${ }^{19}$ It is worth noting that financial institutions can mitigate the negative effects of prepayment penalties on mobilities. For example a prepayment penalty could be applicable for refiancings but not for house sales.
} 
a fully prepayable mortgage. Thus we would expect that the highest quality borrowers will almost surely want to avoid prepayment penalties. By contrast, low credit quality borrowers receive the largest discounts for accepting a prepayment penalty. For these borrowers, the likelihood of mobility or its benefits must be high for them to choose a fully prepayable mortgage.

Overall, in the environment where gains from mobility do not crucially depend on the borrower's risk, our model would predict a higher concentration of mortgages with prepayment penalties among less creditworthy borrowers, as these borrowers obtain the greatest benefits from prepayment penalties. In the empirical section we investigate whether the distribution of prepayment penalties across the measure of borrowers' creditworthiness is consistent with the predictions of our model.

\subsection{Limited Prepayment Penalties}

We have considered a fixed rate mortgage with no refinancing, which has, by definition, a sufficiently high prepayment penalty to discourage refinancing, and a fixed rate mortgage that has no prepayment penalty. One of the predictions of our model is that a prepayment penalty leads to an interest rate reduction. Since loans with a prepayment penalty do not prepay in equilibrium, the interest rate reduction cannot be attributed to the possibility that the borrower pays the prepayment penalty to the lender thus compensating him for the lower interest rate. Instead, we show that the interest rate reduction is welfare improving.

In practice, the size of the prepayment penalty can be limited and borrowers sometimes might choose to prepay their mortgages despite the presence of a prepayment penalty. It is easy to see, however, that considering a finite, limited prepayment penalty will not change the predictions of our model. With a limited prepayment penalty, refinancing, although possible, is going to happen less often. Moreover, even if the borrower's creditworthiness improves sufficiently so that refinancing is beneficial, the lender will be partially compensated with the prepayment penalty. 
Thus, by imposing a finite, limited prepayment penalty, the lender will be able to extend credit to some risky borrowers and lower the mortgage premia compared to loans with no refinancing.

A moderate prepayment penalty might also result from practical trade-offs in a mortgage contract. For example, it could be chosen to allow the borrowers to move at a reasonable cost to realize gains from mobility, but will be sufficiently high to discourage some opportunistic prepayments.

\subsection{Adverse selection}

Another potential concern with our model is the assumption that the lender accurately observes the credit quality of the borrower. That is, lenders know as much about the likelihood of a default using observable information as the borrower. We believe this assumption is reasonable given that the lender can observe income, occupation, credit history, and the loan-to-value ratio of the property. Underwriting experience allows lenders to determine the probability distribution of defaults. Lenders are also likely to be better informed than borrowers about the distribution of future house price changes. ${ }^{20}$

We also do not take into account the possibility that a menu of contracts with and without refinancing penalties could play a role in screening borrowers based on their ex-ante knowledge concerning some relevant variables such as the likelihood of moving ${ }^{21}$. This could be relevant if borrowers were better informed than lenders about the ex-ante riskiness of their income, wealth, or the likelihood of their mobility shocks. In such an environment, the lenders would balance the potential benefits of screening borrowers by offering them contracts with and without refinancing penalties against the costs of decreased ability to insure borrowers.

\footnotetext{
${ }^{20}$ We recognize that possibly poor underwriting standards in the mortgage industry can makes these assumptions less plausible for the 2005 to 2007 time period. This provides an additional advantage of choosing mortgages originated in June 2003 in our empirical exercise.

${ }^{21}$ See for example Chari and Jagannathan (1989), LeRoy (1996), Stanton and Wallace (1998).
} 


\subsection{Non competitive lending, more complex contracts}

Our results were derived in a competitive mortgage lending market with FRM contracts. We conjecture that the inefficiency of refinancing we identified would also apply to other models of competition and environments with more complex contracts ${ }^{22}$, as exclusivity would increase total ex-ante surplus there as well. The relative bargaining powers would determine a share of an additional surplus generated by the exclusive relationship with the lender (due to a prepayment penalty) that the borrower would receive.

\subsection{Stochastic interest rate}

The benefits of prepayment penalties we identify should also be present in a model with stochastic interest rates, as the basic intuition behind the efficiency of borrowers cross-subsidizing each other to hedge against future risks will be valid there as well. ${ }^{23}$

\subsection{General risk aversion}

For the sake of tractability, we assumed risk-neutrality of the borrower with respect to discretionary consumption. A more general form of risk-aversion on the borrower's side would likely strengthen our results as the risk averse borrower would value insurance against costly default, which the lenders can better provide employing refinancing penalties.

\subsection{Endogenous downpayment}

We assumed a constant (zero) downpayment by the borrower. In the health and life insurance context frontloading contributions can help alleviate the problem of reclassification risk. ${ }^{24}$ In the lending context the beneficial role of frontloading through downpayment or points would be much

\footnotetext{
${ }^{22}$ See Piskorski and Tchistyi (2010a, b) who derive an optimal mortgage contract in similar environments.

${ }^{23}$ Piskorski and Tchistyi (2010a) derive an optimal mortgage in a stochastic interest rate environment where full exclusivity (prepayment penalty) is still optimal.

${ }^{24}$ See, for example, Hendel and Lizzeri (2003).
} 
weaker. Those who can spend a lot on points or higher downpayments are likely already good risks. Thus, as these borrowers can receive low mortgage rates, placing a large downpayment might not benefit them a lot. ${ }^{25}$

\section{Empirical Evidence}

The model in the previous section makes a number of predictions that we now examine using data on recently originated fixed rate mortgages. As suggested above, we use house price changes as a proxy for ex-post credit shocks.

One real-world complication in empirically investigating the predictions of our model is that borrowers might prepay to obtain a lower mortgage rate due to lower market interest rates, rather than because of a change in credit status. Our model does not explicitly consider how the addition of interest rate shocks could impact prepayment, though as we discussed in Section 6.7, we are confident that all of our main predictions would still hold. In order to ensure that our empirical work is not biased by the impact of negative interest rate shocks on prepayment, we focus on mortgages originated in June 2003. During that time period, mortgage rates were at their lowest level in the period between 1988 to 2008 (see Figure 2), minimizing the potential value of the prepayment option due to market interest rate changes. By focusing on borrowers who obtained mortgages when the market rate was the lowest in decades, any observed refinancings must be due to factors unrelated to market interest rate declines.

\subsection{Empirical predictions}

Below we develop predictions that are consistent with our model.

Borrowers who receive positive credit shocks are more likely to prepay their mortgages. We

\footnotetext{
${ }^{25}$ This is an important difference with health or life insurance context where the agent's ability to frontload an insurance premium does not necessarily indicate lower likelihood of death or serious illness.
} 
examine mortgages without prepayment penalties to see how likely these mortgages are to prepay in response to house price changes. Our model predicts that borrowers who receive the largest house price increases should be the most likely to prepay early.

The sensitivity of prepayment risk to a positive credit shock is larger for lower credit quality households. Our model suggests that the worst credit risk borrowers benefit the most from positive credit shocks such as an increase in the value of their house, and thus they should be most likely to prepay their mortgages.

The next two predictions are based on our results showing that the benefits from a prepayment penalty are larger for less creditworthy borrowers, as these borrowers are the ones most likely to prepay if they receive a positive credit shock.

Prepayment penalties should be most prevalent among the riskiest borrowers. The prepayment penalty has two benefits for less creditworthy borrowers. First, the riskiest borrowers might not be able to qualify for credit unless they accept a mortgage with a prepayment penalty. Second, those who could qualify for credit with free refinancing obtain a mortgage rate reduction if they accept a prepayment penalty, the larger the riskier they are. On the other hand, a prepayment penalty has virtually no benefit for the most creditworthy borrowers. Thus we would expect a higher concentration of prepayment penalties among riskier borrowers. We examine whether the distribution of prepayment penalties as a function of borrowers' creditworthiness in the data corresponds to the one implied by our model. Finally, our model also implies the following:

Borrowers choosing prepayment penalties obtain rates that are lower than they would have obtained with fully prepayable mortgages (conditional on qualifying for credit), with the largest reductions going to the riskiest borrowers. 


\subsection{Data Summary}

Our primary data comes from LoanPerformance (LP), a subsidiary of First American CoreLogic. LP provides loan-level data on a large number of securitized mortgages. Mayer and Pence (2009) show that the LP data appear relatively representative of the universe of high-cost risky loans, with the exception that refinancings appear to be somewhat over-represented in LP.

LP collects its data at two different times. First, LP collects data on contract terms at the time of origination. In addition, LP also collects data on whether or not the loan has paid off or become delinquent from servicers throughout the life of the mortgage. We create a combined dataset that includes both the characteristics of a loan at origination as well as its monthly payment history.

Within the LP database, we consider only loans with the following characteristics:

A. Loans that were originated in June 2003

B. Fixed interest rate (we do not consider ARMs or hybrid mortgages)

C. Term lengths of 15,20 or 30 years

D. Known prepayment penalty status (some loans have missing values)

E. Located in an MSA with housing price index (HPI) data

F. Collateralized by an owner-occupied 1-4 unit home

We collect HPI data from the Office of Federal Housing Enterprise Oversight. The data are reported at the MSA level and are mapped onto the LP data using a ZIP code to MSA correspondence. The HPI index is normalized to reflect real dollars. Table 1 defines all the variables we use in our analysis.

We consider two subsets of the LP database: prime and subprime. Prime loans are classified by the type of pool they belong to, using definitions that are reported by the issuer of the mortgage-backed security. Prime MBS are backed by high-quality mortgages (that is, mortgages for borrowers with relatively low loan-to value ratios and with very good credit scores), whose 
initial balance typically exceeds the maximum limits for participation by government-sponsored entities Fannie Mae and Freddie Mac. Subprime loans consist of mortgages belonging to pools classified as subprime and having an origination FICO score less than $620 .^{26}$

We focus on fixed-rate mortgages due to complications in understanding prepayment behavior for ARMs that often have teaser rates or other features that complicate the empirical analysis by giving borrowers reasons to refinance mortgages other than changes in their creditworthiness. After all our restrictions, we are left with a sample of 9,046 subprime FRMs (of which 2,517 carry no prepayment penalty) and 9,628 prime FRMs that carry no prepayment penalties in order to investigate the refinancing propensity of the borrowers. ${ }^{27}$

Table 3 reports summary statistics for the securitized loans in our sample that carry no prepayment penalties. In general, loans in prime pools are quite safe along all dimensions and have the mean origination FICO score equal to 738. Subprime loans are much riskier with an average origination FICO score equal to 574. These statistics suggest variation across multiple risk factors that complicate our analysis. Among the categories of loans, subprime loans prepay in the first 16 quarters at much higher rates $(70 \%)$ compared to prime loans (31\%).

Houses also experience quite different rates of price appreciation depending on their location. The mean quarterly real appreciation rate was 1.3 percent (about $5 \%$ annualized), reflecting the strong growth of house prices over our sample period. Thus we would expect relatively few defaults, as borrowers who get into financial trouble can respond by paying off their mortgage by selling their house, often at a profit. However, there is wide dispersion in house price growth rates. The highest-appreciation markets experienced quarterly appreciation rates as high as $3.3 \%$ - almost 14 percent per year for more than 4 years. Slightly less than ten percent of markets saw negative real appreciation rates over this time period.

\footnotetext{
${ }^{26}$ Most lenders define a borrower as subprime if the borrower's FICO credit score is below 620 on a scale that ranges from 300 to 850. See also Keys et al. (2010).

${ }^{27}$ Due to the paucity of prime mortgages with prepayment penalties, we do not examine rate differences for prime mortgages with and without prepayment penalties.
} 
Table 5 reports summary statistics for all securitized subprime loans in our sample, whether or not these mortgages contain a prepayment penalty, and also separately for senior and junior liens. As Table 5 shows, more than 72 percent of subprime loans have a prepayment penalty.

\subsection{Empirical results}

The first two predictions of our model state that the borrowers who receive positive credit shocks are more likely to prepay their mortgages. We begin our analysis by exploring whether the changes in borrowers' creditworthiness proxied for by changes in house prices are an important factor affecting refinancing behavior.

Table 4 presents regressions that explore the prediction that higher house prices spur increased prepayments, so that over time, pools of outstanding loans are disproportionately composed of mortgages in locations with below-average house price appreciation. We use a logit specification with a dependent variable that equals 1 if a loan in a given category pays off and zero otherwise. The independent variable of interest is the annualized rate of house price appreciation. The specifications include a variety of control variables that are commonly associated with loan payoff and risk, including the coupon rate on the mortgage, the borrower's FICO score, cumulative loanto-value ratio, and whether the loan was a refinancing or cash-out refinancing. We run separate regressions for prime and subprime loans. For ease of interpretation, coefficients in all tables reflect marginal effects of a one standard deviation change in the variable about its mean for continuous variables, or a one unit change in the case of discrete variables.

Table 4 shows that, consistent with the first empirical prediction of our model, borrowers in locations where house prices appreciated sharply are more likely to prepay their mortgages compared to borrowers in locations where house prices grew less quickly. The coefficient on annualized house price appreciation is positive and statistically different from zero for subprime borrowers and is positive for prime borrowers. 
Our second empirical prediction is that the sensitivity of prepayment risk to a positive credit shock is larger for lower credit quality household. Consistent with this prediction, we find that the effect of house price appreciation on payoff is much larger (both on an absolute and relative basis) for the riskier subprime loans. As Table 4 shows for prime mortgages, a one standard deviation change in house price appreciation (1.0 percent) leads to a modest 0.6 percent increase in the payoff rate, an increase of about 2 percent of the mean payoff rate of $31 \%$. For the riskier subprime loans, the marginal effect rises to 8.3 percent, a much larger relative increase of 11.8 percent from the mean payoff rate of $70 \%$. These coefficients support the conventional wisdom in the mortgage industry that house price appreciation is an economically important factor in explaining payoff rates for the riskiest mortgages.

Our third empirical prediction says that the riskiest borrowers are the most likely to obtain loans with prepayment penalties. Across the two types of loans, the evidence strongly supports our hypothesis. As Figure 3 shows less than 2 percent of mortgages in prime pools (1.5\%) have prepayment penalties, while 72.2 percent of subprime mortgages have prepayment penalties. The summary statistics of mortgages with and without prepayment penalties also show that mortgages with prepayment penalties are much riskier on observable dimensions, as measured by variables such as FICO or CLTV.

The fourth prediction of our model is that borrowers choosing prepayment penalties obtain rates that are lower than they would have obtained with fully prepayable mortgages (conditional on qualifying for credit), with larger reductions going to riskier borrowers. Empirical investigation of this prediction is challenging as we do not observe a counterfactual in the data: we do not know whether a borrower would qualify for credit for a given house without a prepayment penalty, and if so, what the corresponding mortgage rate would be. Nevertheless, to shed some light on this question, we compare the rates on loans with and without prepayment penalties, controlling for a number of observable risk characteristics. We note that our model implies that borrowers choosing 
prepayment penalties are likely to be less creditworthy (potentially on dimensions not captured by our set of risk controls). Thus, this potential selection on unobservables would make it harder to show that the borrowers with prepayment penalties obtain lower rates.

Table 6 presents the result of regressing the subprime coupon rates on the prepayment penalty status. Consistent with our model, we find that among risky borrowers, mortgages with prepayment penalties carry lower rates compared with loans with free refinancing, with the largest difference for the riskiest loans. Column (1) reports results for all borrowers. The subprime borrowers receive mortgages with a rate that is almost 20 basis points lower (0.195 percent) when a loan has a prepayment penalty. To further investigate this, we compare rates for borrowers for senior and junior liens. Column (2) reports the safer senior liens (the highest priority mortgages) while Column (3) presents results for riskier second liens. These junior mortgages fall behind the first liens in priority and have a very high average CLTV of about $100 \%$. Thus, our model would predict larger discounts for prepayment penalties for riskier second lien borrowers than for first lien borrowers. Consistent with our theory, the mortgage rates of the riskiest junior liens are 62 basis points lower ( 0.625 percent) when their loan has a prepayment penalty, while for the first lien borrowers this difference is 14 basis points (0.139 percent).

These differences in coupon rates between loans with and without prepayment penalties are quite sizable given that the period of applicability of a typical prepayment penalty is limited. For example, among subprime loans originated in 2003, the average penalty lasted only for about three years. $^{28}$

While the percentage of subprime borrowers with fully prepayable loans is relatively low (less than 30 percent), the question naturally arises as to why low credit quality borrowers would not always have prepayment penalties if the higher mortgage rates often lead to greater defaults. Our earlier discussion suggests that restricted mobility may impose additional costs that might more

\footnotetext{
${ }^{28}$ See Chomsisengphet and Pennington-Cross (2006).
} 
than offset the benefit of lower mortgage rates that usually accompany a prepayment penalty. Thus, some borrowers with a high likelihood of moving might accept higher rates and a greater risk of default to compensate for avoiding being locked into their homes. In addition, in a number of states, there are legal restrictions on the usage of prepayment penalties by lenders. ${ }^{29}$

\section{Concluding Remarks}

Critics of subprime mortgages often point to a high concentration of prepayment penalties among less creditworthy borrowers as evidence of predatory lending. They argue that prepayment penalties unfairly lock risky borrowers into mortgages with high interest payments, accusing mortgage originators of abusing naive borrowers who do not fully understand mortgage terms.

This paper shows that in a competitive lending model, refinancing penalties can be welfare improving, and that they can be particularly beneficial to riskier borrowers in the form of lower mortgage rates, reduced defaults, and extension of credit. Thus, a high concentration of prepayment penalties among the least creditworthy borrowers can be an outcome of efficient and fair lending. Our empirical results are consistent with the key predictions of our model. Overall, our findings highlight the importance of considering dynamic features of credit contracts in order to understand the impact of specific lending terms.

Our model suggests that regulations banning refinancing penalties might have unintended consequences. Instead of protecting the riskiest would-be homeowners from predatory lending, the new law might end up protecting them from credit. As we focus on 2003 originations in this paper, we recognize that underwriting standards could have changed in the years just preceding the crisis. However, prepayment penalties are used in many other countries besides the United States, seemingly without the perceived negative consequences that accompanied U.S. subprime loans with

\footnotetext{
${ }^{29}$ Note that our empirical specifications for coupon rate include location specific (MSA) fixed effects.
} 
prepayment penalties. ${ }^{30}$ Thus, refinancing penalties could be a part of a refashioned mortgage product that helps riskier borrowers obtain credit. This might require appropriate disclosure and counseling to ensure that borrowers understand the terms of their mortgage and the implications of a prepayment penalty.

\footnotetext{
${ }^{30}$ Mayer et al. (2009) argue that the high default rates associated with subprime and alt-A mortgages were related to deficiencies in underwriting rather than flaws with terms of the mortgage products themselves.
} 


\section{Appendix}

\section{Proof of Proposition 1}

First we show that the solution to (3)-(6) is concave in $S$. Consider a function

$$
F(S, \bar{\phi})=\bar{U}(S, \bar{\phi})-S
$$

where $\bar{U}(S, \bar{\phi})$ is a solution to (3)-(6). From (3)-(6) we have that

$$
\begin{aligned}
\gamma F(S, \bar{\phi}) & =\mu+\theta-\bar{\phi}+(r S+\mu-\bar{\phi}) F^{\prime}(S, \bar{\phi})-(\gamma-r) W+\frac{1}{2} \sigma^{2} F^{\prime \prime}(S, \bar{\phi}) \text { for } S \in\left[0, S^{1}(\bar{\phi})\right] \\
F(0, \bar{\phi}) & =A \\
F^{\prime}(S, \bar{\phi}) & =0 \text { for } S \geq S^{1}(\bar{\phi}), \\
F^{\prime \prime}(S, \bar{\phi}) & =0 \text { for } S \geq S^{1}(\bar{\phi}) .
\end{aligned}
$$

As the solution $F$ is smooth we can differentiate it with respect to $S$ to obtain:

$$
(\gamma-r) F^{\prime}(S, \bar{\phi})=(r S+\mu-\bar{\phi}) F^{\prime \prime}(S, \bar{\phi})-(\gamma-r)+\frac{1}{2} \sigma^{2} F^{\prime \prime \prime}(S, \bar{\phi}) \text { for } S \in\left[0, S^{1}(\bar{\phi})\right]
$$

Evaluating the above equation at $S=S^{1}(\bar{\phi})$ yields

$$
F_{-}^{\prime \prime \prime}\left(S^{1}(\bar{\phi}), \bar{\phi}\right)=\frac{2(\gamma-r)}{\sigma^{2}}>0
$$

Note that as $F^{\prime \prime}\left(S^{1}(\bar{\phi}), \bar{\phi}\right)=0$ and we have that $F_{-}^{\prime \prime \prime}\left(S^{1}(\bar{\phi}), \bar{\phi}\right)>0$ it implies that there exists $\varepsilon>0$ such that $F^{\prime \prime}<0$ over the interval $\left(S^{1}(\bar{\phi})-\varepsilon, S^{1}(\bar{\phi})\right)$. Also as $F^{\prime}\left(S^{1}(\bar{\phi}), \bar{\phi}\right)=0$ and $F^{\prime \prime}\left(S^{1}(\bar{\phi}), \bar{\phi}\right)<0$ over the interval $\left(S^{1}(\bar{\phi})-\varepsilon, S^{1}(\bar{\phi})\right)$ it implies that $F^{\prime}>0$ over the interval $\left(S^{1}(\bar{\phi})-\varepsilon, S^{1}(\bar{\phi})\right)$. 
From (3) we have that

$$
F^{\prime \prime}(S, \bar{\phi})=\frac{2\left[\gamma F(S, \bar{\phi})-[\mu+\theta-\bar{\phi}-(\gamma-r) S]-(r S+\mu-\bar{\phi}) F^{\prime}(S, \bar{\phi})\right]}{\sigma^{2}} .
$$

As $\bar{\phi} \leq \theta$ and as by assumption $\theta \leq \mu$ we have that $\mu-\bar{\phi} \geq 0$. Hence from (20) whenever: (i) $\gamma F(S, \bar{\phi})<[\mu+\theta-\bar{\phi}-(\gamma-r) S]$ and (ii) $F^{\prime}(S, \bar{\phi})>0$ holds it follows that $F^{\prime \prime}<0$. Now since $\gamma F\left(S^{1}(\bar{\phi}), \bar{\phi}\right)=\mu+\theta-\bar{\phi}-(\gamma-r) S^{1}(\bar{\phi})$ and $F^{\prime}>0$ over the interval $\left(S^{1}(\bar{\phi})-\varepsilon, S^{1}(\bar{\phi})\right)$ it follows that these conditions are satisfied over the interval $\left(S^{1}(\bar{\phi})-\varepsilon, S^{1}(\bar{\phi})\right)$. Moreover, (i) will hold for any $S \in\left[0, S^{1}(\bar{\phi})\right)$ as long as $F$ remains strictly increasing, i.e. as long as $F^{\prime}>0$.

Now suppose by contradiction that $F^{\prime} \leq 0$ for some $S \leq S^{1}(\bar{\phi})-\varepsilon$ and let

$$
\tilde{S}=\sup \left\{S \leq S^{1}(\bar{\phi})-\varepsilon \mid F^{\prime} \leq 0\right\}
$$

Then it follows that $F^{\prime}(\tilde{S}, \bar{\phi})=0$, and that for all $S \in\left(\tilde{S}, S^{1}(\bar{\phi})\right)$ we have that $F^{\prime}>0$ and so (i) and (ii) holds. But this implies that $F^{\prime \prime}<0$ for $S \in\left(\tilde{S}, S^{1}(\bar{\phi})\right)$. From the Fundamental Theorem of Calculus it follows that:

$$
\left.S^{\prime}(b)\right)+\int_{\tilde{S}}^{S^{1}(\bar{\phi})} F^{\prime \prime}(S, \bar{\phi}) d S,
$$

which given that $S^{\prime}\left(S^{1}(\bar{\phi}), \bar{\phi}\right)=0$ implies that

$$
F^{\prime}\left(\tilde{S}, S^{1}(\bar{\phi})\right)=-\int_{\tilde{S}}^{S^{1}(\bar{\phi})} F^{\prime \prime}(S, \bar{\phi}) d S
$$

As $F^{\prime \prime}<0$ for $S \in\left(\tilde{S}, S^{1}(\bar{\phi})\right)$ the above implies that $F^{\prime}\left(\tilde{S}, S^{1}(\bar{\phi})\right)>0$, which is a contradiction. Hence we have that $F^{\prime}>0$ for $S \in\left(0, S^{1}(\bar{\phi})\right)$ and hence (i) and (ii) holds and so $F^{\prime \prime}<0$ for $S \in\left(0, S^{1}(\bar{\phi})\right)$. But this implies that $\bar{U}^{\prime}(S, \bar{\phi})>1$ and $\bar{U}^{\prime \prime}(S, \bar{\phi})<0$ for $S \in\left(\tilde{S}, S^{1}(\bar{\phi})\right)$. 
We note that Conditions (5)-(6) imply that

$$
\gamma \bar{U}\left(S^{1}(\bar{\phi}), \bar{\phi}\right)=\theta+\mu-\bar{\phi}+r S^{1}(\bar{\phi})
$$

The borrower's savings (wealth) evolves according to

$$
d S_{t}=\left(r S_{t}+\mu-\bar{\phi}\right) d t+\sigma d Z_{t}-d C_{t}
$$

For an arbitrary feasible strategy $(C, S)$, consider

$$
G_{t} \equiv \int_{0}^{t} e^{-\gamma s}\left(d C_{s}+\theta d s\right)+e^{-\gamma t} \bar{U}\left(S_{t}, \bar{\phi}\right)
$$

where function $\bar{U}$ satisfies all the conditions outlined in Proposition 1 . We will show that $G_{t}$ is a supermartingale. Differentiating (22) with respect to $t$ and using Ito's lemma gives

$$
\begin{aligned}
e^{\gamma t} d G_{t}= & {\left[-\gamma \bar{U}\left(S_{t}, \bar{\phi}\right)+\theta+\left(r S_{t}+\mu-\bar{\phi}\right) \bar{U}^{\prime}\left(S_{t}, \bar{\phi}\right)+0.5 \sigma^{2} \bar{U}^{\prime \prime}\left(S_{t}, \bar{\phi}\right)\right] d t } \\
& +\left(1-\bar{U}^{\prime}\left(S_{t}, \bar{\phi}\right)\right) d C_{t}+\bar{U}^{\prime}\left(S_{t}, \bar{\phi}\right) \sigma d Z_{t} .
\end{aligned}
$$

When $S_{t} \leq S^{1}(\bar{\phi})$, the first term in the right-hand side of (23) is zero, because of (3). When $S_{t}>S^{1}(\bar{\phi})$, the first term is negative, because of (5), (6), (21) and the fact $\gamma>\rho$. Since $\bar{U}^{\prime}\left(S_{t}, \bar{\phi}\right) \geq 1$ and $d C_{t} \geq 0, G_{t}$ is a supermartingale.

$$
\begin{aligned}
E\left[\int_{0}^{\tau} e^{-\gamma s}\left(d C_{s}+\theta d s\right)+e^{-\gamma \tau} A\right] & =E\left[\int_{0}^{\tau} e^{-\gamma s}\left(d C_{s}+\theta d s\right)+e^{-\gamma \tau} S_{\tau}\right] \\
& =E\left[G_{\tau}\right] \leq G_{0}=\bar{U}\left(S_{0}, \bar{\phi}\right)
\end{aligned}
$$

Thus, the agent's payoff associated with strategy $(C, W)$ is less than or equal to $\bar{U}\left(S_{0}, \bar{\phi}\right)$.

If the agent has zero consumption whenever $S_{t} \in\left[0, S^{1}(\bar{\phi})\right]$ and consumes $S_{t}-S^{1}(\bar{\phi})$ imme- 
diately whenever $S_{t}>S^{1}(\bar{\phi})$, then $G_{t}$ is a martingale and (24) holds with equality. Hence, this is the optimal strategy, which results in $\bar{U}\left(S_{0}, \bar{\phi}\right)$ payoff to the agent.

\section{Proof of Proposition 2}

First we prove the following Lemma.

Lemma 3 The maximum savings level of the borrower, $S^{1}\left(\bar{\phi}^{*}\right)$, is strictly increasing in the competitive mortgage repayment rate on the FRM with no refinancing $\bar{\phi}^{*}$.

Proof Differentiating equation (21) with respect to $\bar{\phi}$ and taking into account (5) gives

$$
\frac{\partial S^{1}\left(\bar{\phi}^{*}\right)}{\partial \bar{\phi}^{*}}=-\frac{1+\frac{\partial \bar{U}\left(S^{1}\left(\bar{\phi}^{*}\right), \bar{\phi}^{*}\right)}{\partial \bar{\phi}^{*}}}{\gamma-r} .
$$

According to Feynman-Kac formula,

$$
\frac{\partial \bar{U}\left(S^{1}\left(\bar{\phi}^{*}\right), \bar{\phi}^{*}\right)}{\partial \bar{\phi}^{*}}=-E\left[\int_{0}^{\tau\left(S^{1}\left(\bar{\phi}^{*}\right), \bar{\phi}^{*}\right)} e^{-\gamma t} \frac{\partial \bar{U}\left(S_{t}, \bar{\phi}^{*}\right)}{\partial S_{t}} d t \mid S_{0}=S^{1}\left(\bar{\phi}^{*}\right)\right] .
$$

Since $\frac{\partial \bar{U}\left(S_{t}, \bar{\phi}^{*}\right)}{\partial S_{t}} \geq 1$, we can write that

$$
-\frac{\partial \bar{U}\left(S^{1}\left(\bar{\phi}^{*}\right), \bar{\phi}^{*}\right)}{\partial \bar{\phi}^{*}} \geq E\left[\int_{0}^{\tau\left(S^{1}\left(\bar{\phi}^{*}\right), \bar{\phi}^{*}\right)} e^{-\gamma t} d t\right]=\frac{1}{\gamma}\left(1-E\left[e^{-\gamma \tau\left(S^{1}\left(\bar{\phi}^{*}\right), \bar{\phi}^{*}\right)}\right]\right) .
$$

On the other hand, since $S_{0} \leq S^{1}\left(\bar{\phi}^{*}\right)$ and $r<\gamma$ we can write that

$$
\begin{aligned}
P & =V\left(S_{0}, \bar{\phi}^{*}\right) \leq V\left(S^{1}\left(\bar{\phi}^{*}\right), \bar{\phi}^{*}\right)=\frac{\bar{\phi}^{*}}{r}-\left(\frac{\bar{\phi}^{*}}{r}-L\right) E\left[e^{-r \tau\left(S^{1}\left(\bar{\phi}^{*}\right), \bar{\phi}^{*}\right)}\right] \\
& <\frac{\bar{\phi}^{*}}{r}-\left(\frac{\bar{\phi}^{*}}{r}-L\right) E\left[e^{-\gamma \tau\left(S^{1}\left(\bar{\phi}^{*}\right), \bar{\phi}^{*}\right)}\right]
\end{aligned}
$$


which gives

$$
E\left[e^{-\gamma \tau\left(S^{1}\left(\bar{\phi}^{*}\right), \bar{\phi}^{*}\right)}\right] \leq \frac{\frac{\bar{\phi}^{*}}{r}-P}{\frac{\bar{\phi}^{*}}{r}-L}
$$

Hence,

$$
-\frac{\partial \bar{U}\left(S^{1}\left(\bar{\phi}^{*}\right), \bar{\phi}^{*}\right)}{\partial \bar{\phi}^{*}} \geq \frac{1}{\gamma}\left(1-\frac{\frac{\bar{\phi}^{*}}{r}-P}{\frac{\bar{\phi}^{*}}{r}-L}\right)=1+\frac{P-\left(\gamma \frac{\bar{\phi}^{*}}{r}+(1-\gamma) L\right)}{\gamma\left(\frac{\bar{\phi}^{*}}{r}-L\right)} .
$$

Noting that $\bar{\phi}^{*} \leq \theta$ (Lemma 1), and as $\theta \leq \frac{r[P-(1-\gamma) L]}{\gamma}$ (as by assumption $P-L \geq \gamma\left(\frac{\theta}{r}-L\right)$ ) we have that $P \geq \gamma \frac{\bar{\phi}^{*}}{r}+(1-\gamma) L$. But this implies that $\frac{\partial \bar{U}\left(S^{1}\left(\bar{\phi}^{*}\right), \bar{\phi}^{*}\right)}{\partial \bar{\phi}^{*}}<-1$ and so $\frac{\partial S^{1}\left(\bar{\phi}^{*}\right)}{\partial \bar{\phi}^{*}}>0$.

Now let's take any $S_{0} \leq S^{1}\left(\bar{\phi}^{*}\left(S_{0}\right)\right)$. Consider $S_{0}^{\prime}<S_{0}$. Let's suppose that by contradiction $\bar{\phi}^{*}\left(S_{0}^{\prime}\right)<\bar{\phi}^{*}\left(S_{0}\right)$. But this and Lemma 3 imply that $S^{1}\left(\bar{\phi}^{*}\left(S_{0}^{\prime}\right)\right)<S^{1}\left(\bar{\phi}^{*}\left(S_{0}^{\prime}\right)\right)$, which implies that $\tau\left(S_{0}, \bar{\phi}^{*}\left(S_{0}\right)\right)>\tau\left(S_{0}^{\prime}, \bar{\phi}^{*}\left(S_{0}^{\prime}\right)\right)\left(\right.$ as both $S_{0}^{\prime}<S_{0}$ and $\left.S^{1}\left(\bar{\phi}^{*}\left(S_{0}^{\prime}\right)\right)<S^{1}\left(\bar{\phi}^{*}\left(S_{0}^{\prime}\right)\right)\right)$. But this implies that

$$
\begin{aligned}
P & =\underbrace{\frac{\bar{\phi}^{*}\left(S_{0}\right)}{r}-E\left[e^{-r \tau\left(S_{0}, \bar{\phi}^{*}\left(S_{0}\right)\right)}\left(\frac{\bar{\phi}^{*}\left(S_{0}\right)}{r}-L\right) \mid \mathcal{F}_{0}\right]}_{V_{0}\left(S_{0}, \bar{\phi}^{*}\left(S_{0}\right)\right)} \\
> & \underbrace{\frac{\bar{\phi}^{*}\left(S_{0}^{\prime}\right)}{r}-E\left[e^{-r \tau\left(S_{0}^{\prime}, \bar{\phi}^{*}\left(S_{0}^{\prime}\right)\right)}\left(\frac{\bar{\phi}^{*}\left(S_{0}^{\prime}\right)}{r}-L\right) \mid \mathcal{F}_{0}\right]}_{V_{0}\left(S_{0}^{\prime}, \bar{\phi}^{*}\left(S_{0}^{\prime}\right)\right)},
\end{aligned}
$$

which contradicts $V_{0}\left(S_{0}^{\prime}, \bar{\phi}^{*}\left(S_{0}^{\prime}\right)\right)=P$. Therefore we have that the competitive mortgage rate on FRM with no refinancing, $\phi^{*}$, is strictly decreasing on $[\underline{S}, \bar{S}]$, where $\bar{S}$ is the savings level of the most creditworthy borrower. Moreover

$$
\bar{S}=\inf _{S \geq \underline{S}}\left\{S^{1}\left(\bar{\phi}^{*}(S)\right)\right\}
$$

as we have that $\frac{d \bar{\phi}^{*}(S)}{d S}<0$ for $S \in[\underline{S}, \bar{S}]$ and $\frac{\partial S^{1}\left(\bar{\phi}^{*}\right)}{\partial \bar{\phi}^{*}}>0$ (Lemma 3$)$. 


\section{Proof of Proposition 3}

The proof of (7)-(9) is essentially the same as the proof of Proposition 1, except that the boundary condition (5)-(6) is replaced with (9).

The proof of (10)-(12) follows from the Feynman-Kac stochastic representation formula and the fact that the mortgage market value $V^{n}(S, \phi)$ is given by

$$
V^{n}(S, \phi)=E\left[\int_{0}^{\min \left(\tau, \tau^{n}\right)} e^{-r t} \phi d t+e^{-r \min \left(\tau, \tau^{n}\right)}\left(L+1_{\tau^{n}<\tau}(P-L)\right)\right]
$$

where the default and refinancing times are

$$
\begin{aligned}
\tau & =\inf \left\{t>0: S_{t}=0\right\}, \\
\tau^{n} & =\inf \left\{t>0: S_{t}=S_{S_{0}}^{n+1}\right\},
\end{aligned}
$$

and the savings level evolves as follows

$$
d S_{t}=r S_{t} d t+\mu d t+\sigma d Z_{t}-\phi^{n} d t \text { on }\left[0, S_{S_{0}}^{n+1}\right]
$$




\section{References}

Ait-Sahalia, Yacine, Jonathan Parker, and Motohiro Yogo, 2004, Luxury goods and the equity premium, Journal of Finance 59, 2959-3004.

Campbell, John Y., and João F. Cocco, 2003, Household risk management and optimal mortgage choice, Quarterly Journal of Economics 118, 1449-1494.

Campbell, John Y., and João F. Cocco, 2007, How do house prices affect consumption? Evidence from micro data, Journal of Monetary Economics 54, 591-621.

Chari, Varadarajan V., and Ravi Jagannathan, 1989, Adverse selection in a model of real estate lending, Journal of Finance 44, 499-508.

Chomsisengphet, Souphala, and Anthony Pennington-Cross, 2006, The evolution of the subprime mortgage market, Federal Reserve Bank of St. Louis Review January/February 2006.

Cocco, João F., 2004, Portfolio choice in the presence of housing, Review of Financial Studies $18,535-567$.

Cochrane, John., 1995, Time consistent health insurance, Journal of Political Economy 103, 445-473.

Demyanyk, Yuliya and Otto Van Hemert, Otto, 2008, Understanding the subprime mortgage crisis, forthcoming in the Review of Financial Studies.

Deng, Yonheng, John Quigley, and Robert Van Order, 2000,Mortgage termination, heterogeneity, and the exercise of mortgage options, Econometrica 68, 275-307.

Dunn, Kenneth B., and John J. McConnell, 1981, Valuation of GNMA Mortgage-Backed Securities, Journal of Finance 36, 599-617. 
Dunn, Kenneth B., and Chester S. Spatt, 1985, An analysis of mortgage contracting: Prepayment penalties and the due-on-sale clause, Journal of Finance 40, 293-308.

Chapman, M. Findlay III and Dennis R. Capozza, 1977, The Variable-Rate Mortgage and Risk in the Mortgage Market: An Option Theory Perspective:Note, Journal of Money, Credit and Banking 9, 356-364.

Hendel, Igal E., and Alessandro Lizzeri, 2003, The role of commitment in dynamic contracts: Evidence from life insurance, Quarterly Journal of Economics 118, 299-327.

Kau, James B., Donald C. Keenan, Walter J. III Muller, and James F. Epperson, 1992, A generalized valuation model for fixed-rate residential mortgages, Journal of Money, Credit and Banking 24, 279-299.

Keys, Benjamin, Tanmoy Mukherjee, Amit Seru, and Vikrant Vig, 2010, Did securitization lead to lax screening: Evidence from subprime loans, Quarterly Journal of Economics 125, 307362.

Koijen, Ralph, Otto Van Hemert, and Stijn Van Nieuwerburgh, 2009, Mortgage timing, Journal of Financial Economics 93, 292-324.

LeRoy, Stephen F., 1996, Mortgage valuation under optimal prepayment, Review of Financial Studies 9, 817-844.

Manso, Gustavo, Bruno Strulovici, and Alexei Tchistyi, 2010, Performance-sensitive debt, Review of Financial Studies 23, 1819-1854.

Mayer, Christopher, Karen Pence, and Shane Sherlund, 2009, The rise in mortgage defaults, Journal of Economic Perspectives 23, 27-50.

Mian, Atif, and Amir Sufi, 2009, The Consequences of mortgage credit expansion: Evidence from the U.S. mortgage default crisis, Quarterly Journal of Economics 124, 1449-1496. 
Mian, Atif, and Amir Sufi, 2010, House prices, home equity-based borrowing, and the U.S. household leverage crisis, forthcoming in the American Economic Review.

Ortalo-Magné, François, and Sven Rady, 2006, Housing market dynamics: On the contribution of income shocks and credit constraints, Review of Economic Studies 73, 459-485.

Peterson, Mitchell, and Raghuram G. Rajan, 1995, The effect of credit market competition on lending relationships, Quarterly Journal of Economics 110, 407-43.

Piskorski, Tomasz, and Alexei Tchistyi, 2010a, Optimal mortgage design, Review of Financial Studies 23, 3098-3140.

Piskorski, Tomasz, and Alexei Tchistyi, 2010b, Stochastic house appreciation and optimal mortgage lending, forthcoming in the Review of Financial Studies.

Piskorski, Tomasz, Amit Seru, and Vikrant Vig, 2010, Securitization and distressed loan renegotiation: Evidence from the subprime mortgage crisis, Journal of Financial Economics 97, 369-397.

Rajan, Uday, Amit Seru, and Vikrant Vig, 2010, The failure of models that predict failure: Distance, incentives and defaults, working paper.

Schwartz, Eduardo S., and Walter Torous, 1989, Prepayment and the valuation of mortgagebacked securities, Journal of Finance 44, 375-392.

Spiegel, Matthew, and William Strange, 1992, A theory of predictable excess returns in real estate, Journal of Real Estate Finance and Economics 5, 375-392.

Spiegel, Matthew, 2001, Housing return and construction cycles, Real Estate Economics 29, $521-551$. 
Stanton, Richard H., 1995, Rational Prepayment and the Valuation of Mortgage-Backed Securities, Review of Financial Studies 8, 677-708.

Stanton, Richard H., and Nancy Wallace, 1998, Mortgage choice: What is the point?, Real Estate Economics 26, 173-205. 
Table 1: Parameters of the model

\begin{tabular}{ccccccccc}
\hline $\begin{array}{c}\text { Interest } \\
\text { rate }\end{array}$ & $\begin{array}{c}\text { Borrower's } \\
\text { discount rate }\end{array}$ & process & homeownership & reservation values & (loan amount) \\
\hline$r$ & $\gamma$ & $\mu$ & $\sigma$ & $\theta$ & $A$ & $L$ & $R\left(S_{0}\right)$ & $P$ \\
\hline $3 \%$ & $5 \%$ & 1 & 0.2 & 1 & 20 & 14 & $\frac{\mu}{\gamma}+S_{0}$ & 18 \\
\hline
\end{tabular}


Table 2: Variables description

Pays Off in 16Qs

Average Quarterly HPI Growth

Prepayment Penalty

Coupon Rate

Origination Amount

FICO

Lien

Senior has Juniors

Loan is Subprime

CLTV

Loan Purpose

Documentation

Term
A variable that is 1 if the loan pays off in full (except through foreclosure) from time of origination through June 2007.

This variable is the quarterly, real HPI growth from June 2003 to June 2007

A variable that is 1 if the loan contains a prepayment penalty of any sort and 0 otherwise.

The monthly interest rate charged to the borrower.

Origination amount in thousands of dollars.

The credit score of the borrower using the FICO credit profile.

A variable that is either senior for loans in the first position or subordinate for loans that are not in the senior position. Senior is the reference variable in the following regressions.

A Variable that is 1 when the first lien loan is known to have a junior on top and 0 otherwise.

A variable that is 1 when the loan is classified as Subprime.

A variable that, for junior liens, is the Loan-to-Value ratio calculated as the sum of the value of all liens against the home over the value of the home. For Senior (first) lien loans, due to the fact that we do not observe the value of additional liens, we use the as the LTV the ratio of the first loan amount to the value of the home.

A variable that is either For Purchase, Cash Out Refinance or No Cash Out Refinance. For Purchase is the reference variable in the following regressions

A variable that is Full Documentation, Low Documentation or No Documentation. Full Documentation is the reference variable in the following regressions.

A categorical variable for the length of the term. It is either 10 years, 15 years, or 30 years. 30 years is the reference variable in the following regressions. 
Table 3: Summary statistics for FRM loans with no prepayment penalties

\begin{tabular}{|c|c|c|c|c|c|c|c|c|}
\hline & \multicolumn{4}{|c|}{ Subprime } & \multicolumn{4}{|c|}{ Prime } \\
\hline & Mean & Median & Std. Dev. & Count & Mean & Median & Std. Dev. & Count \\
\hline Pays Off in 16Qs & 0.702 & 1 & 0.457 & 2,517 & 0.314 & 0 & 0.464 & 9,631 \\
\hline Average Quarterly HPI Growth & 0.011 & 0.009 & 0.009 & 2,517 & 0.018 & 0.018 & 0.009 & 9,631 \\
\hline Prepayment Penalty & 0 & 0 & 0 & 2,517 & 0 & 0 & 0 & 9,631 \\
\hline Coupon Rate & 9.075 & 8.75 & 1.905 & 2,517 & 5.478 & 5.5 & 0.361 & 9,631 \\
\hline Origination Amount & 110.6 & 83.5 & 88.8 & 2,517 & 485.5 & 448.5 & 164.9 & 9,631 \\
\hline CLTV* & 80 & 80 & 15 & 2,517 & 63 & 66 & 15 & 9,631 \\
\hline FICO & 574.4 & 580 & 32.045 & 2,517 & 738.9 & 748 & 40.932 & 9,631 \\
\hline Refinance - No Cash & 0.124 & 0 & 0.329 & 2,517 & 0.636 & 1 & 0.481 & 9,631 \\
\hline Refinance - Cash Out & 0.648 & 1 & 0.478 & 2,517 & 0.193 & 0 & 0.394 & 9,631 \\
\hline Low Documentation & 0.18 & 0 & 0.384 & 2,517 & 0.289 & 0 & 0.453 & 9,631 \\
\hline No Documentation & 0.004 & 0 & 0.063 & 2,517 & 0.067 & 0 & 0.25 & 9,631 \\
\hline 15 Year Term & 0.132 & 0 & 0.338 & 2,517 & 0.395 & 0 & 0.489 & 9,631 \\
\hline 20 Year Term & 0.162 & 0 & 0.369 & 2,517 & 0.008 & 0 & 0.09 & 9,631 \\
\hline Senior has Juniors & 0.009 & 0 & 0.093 & 2,517 & 0.09 & 0 & 0.286 & 9,631 \\
\hline Subordinate Lien & 0.205 & 0 & 0.404 & 2,517 & 0 & 0 & 0 & 9,631 \\
\hline \multicolumn{9}{|c|}{$\begin{array}{l}\text { Owner Occupied FRM loans with out a prepayment penalty originated during June } 2003 \text { from the LoanPerformance (LP) databases. } \\
\text { Loans with buydown or IO provisions are excluded along with loans with FICO scores under } 500 \text {. We include only purchase and } \\
\text { refinance loans on } 1-4 \text { family homes with term lengths of } 15,20 \text { or } 30 \text { years. Only loans in Metropolitan Statistical Areas (MSAs) } \\
\text { with at least } 5 \text { observations are included. Payoff is defined as voluntary prepayment (foreclosures are excluded). Housing price } \\
\text { growth is calculated using OFHEO MSA level data. }\end{array}$} \\
\hline
\end{tabular}


Table 4: Logit marginal effects for loans with no prepayment penalties

\begin{tabular}{|c|c|c|}
\hline & Subprime & Prime \\
\hline Dependent Variable & Pays Off in 16Qs & Pays Off in 16Qs \\
\hline Dependent Variable Mean & 0.702 & 0.314 \\
\hline Average Quarterly HPI Growth & $\begin{array}{l}\mathbf{0 . 0 8 3} \\
(7.19)\end{array}$ & $\begin{array}{l}\mathbf{0 . 0 0 6} \\
(1.18)\end{array}$ \\
\hline Coupon Rate & $\begin{array}{c}0.08763 \\
(6.64)\end{array}$ & $\begin{array}{c}0.12996 \\
(7.56)\end{array}$ \\
\hline FICO & $\begin{array}{c}0.288405 \\
(1.18)\end{array}$ & $\begin{array}{c}0.20466 \\
(1.82)\end{array}$ \\
\hline FICO Squared & $\begin{array}{l}-0.000 \\
(-1.14)\end{array}$ & $\begin{array}{l}-0.000 \\
(-2.11)\end{array}$ \\
\hline Origination Amount & $\begin{array}{l}0.266 \\
(6.91)\end{array}$ & $\begin{array}{l}-0.000 \\
(-1.25)\end{array}$ \\
\hline Origination Amount Squared & $\begin{array}{l}-0.000 \\
(-6.37)\end{array}$ & $\begin{array}{l}0.000 \\
(0.32)\end{array}$ \\
\hline CLTV above 97 (d) & $\begin{array}{l}-0.015 \\
(-0.29)\end{array}$ & \\
\hline CLTV 90 to 97 (d) & $\begin{array}{l}-0.006 \\
(-0.16)\end{array}$ & $\begin{array}{l}0.219 \\
(4.32)\end{array}$ \\
\hline CLTV 80 to 90 (d) & $\begin{array}{l}-0.052 \\
(-2.37)\end{array}$ & $\begin{array}{l}0.057 \\
(3.83)\end{array}$ \\
\hline Refinance No Cash Out (d) & $\begin{array}{l}-0.082 \\
(-1.88)\end{array}$ & $\begin{array}{l}0.035 \\
(2.41)\end{array}$ \\
\hline Refinance Cash Out (d) & $\begin{array}{l}-0.086 \\
(-3.31)\end{array}$ & $\begin{array}{l}0.042 \\
(2.11)\end{array}$ \\
\hline Low Documentation $\quad$ (d) & $\begin{array}{l}-0.036 \\
(-1.32)\end{array}$ & $\begin{array}{l}0.009 \\
(0.60)\end{array}$ \\
\hline No Documentation (d) & $\begin{array}{l}-0.306 \\
(-2.33)\end{array}$ & $\begin{array}{l}-0.032 \\
(-1.57)\end{array}$ \\
\hline 15 Year Term (d) & $\begin{array}{l}-0.002 \\
(-0.06)\end{array}$ & $\begin{array}{l}0.208 \\
(5.85)\end{array}$ \\
\hline 20 Year Term (d) & $\begin{array}{l}0.026 \\
(0.78)\end{array}$ & $\begin{array}{l}0.032 \\
(0.68)\end{array}$ \\
\hline Senior has Juniors (d) & $\begin{array}{l}0.113 \\
(1.52)\end{array}$ & $\begin{array}{l}0.101 \\
(5.08)\end{array}$ \\
\hline Junior Lien (d) & $\begin{array}{l}0.164 \\
(3.48)\end{array}$ & \\
\hline Count & 2,517 & 9,628 \\
\hline
\end{tabular}

Owner Occupied FRM loans with out a prepayment penalty originated during June 2003 from the LoanPerformance (LP) databases. We include only purchase and refinance loans on 1-4 family homes with term lengths of 15,20 or 30 years. Only loans in Metropolitan Statistical Areas (MSAs) with at least 5 observations are included. Payoff is defined as voluntary prepayment (foreclosures are excluded). House price growth is calculated using OFHEO MSA level data.

Coefficients reported are Marginal Effects from a logistic regression. Dummy (discrete) variables are marked with a (d) after the variable name. Continuous variables report the marginal effect multiplied the standard deviation of the right hand side variable. T-statistics are in parenthesis. 
Table 5: Summary statistics for FRM subprime loans both with and without prepayment penalties

\begin{tabular}{|c|c|c|c|c|c|c|c|c|c|c|c|c|}
\hline \multirow[b]{3}{*}{ Pays Off in 16Qs } & \multicolumn{4}{|c|}{ Subprime: All Liens } & \multicolumn{4}{|c|}{ Subprime: Senior Liens } & \multicolumn{4}{|c|}{ Subprime: Junior Liens } \\
\hline & Mean & Median & $\begin{array}{l}\text { Std. } \\
\text { Dev. }\end{array}$ & Count & Mean & Median & $\begin{array}{l}\text { Std. } \\
\text { Dev. }\end{array}$ & Count & Mean & Median & $\begin{array}{l}\text { Std. } \\
\text { Dev. }\end{array}$ & Count \\
\hline & 0.722 & 1 & 0.448 & 9,046 & 0.697 & 1 & 0.459 & 7,945 & 0.903 & 1 & 0.296 & 1,101 \\
\hline $\begin{array}{l}\text { Average Quarterly HPI } \\
\text { Growth in } 16 \mathrm{Q} \text { s }\end{array}$ & 0.016 & 0.018 & 0.012 & 9,046 & 0.016 & 0.019 & 0.012 & 7,945 & 0.016 & 0.018 & 0.012 & 1,101 \\
\hline Prepayment Penalty & 0.722 & 1 & 0.448 & 9,046 & 0.748 & 1 & 0.434 & 7,945 & 0.53 & 1 & 0.499 & 1,101 \\
\hline Coupon Rate & 8.363 & 7.99 & 1.635 & 9,046 & 7.956 & 7.8 & 1.204 & 7,945 & 11.304 & 11.24 & 1.281 & 1,101 \\
\hline Origination Amount & 133.86 & 110.50 & 92.44 & 9,046 & 147.09 & 124.80 & 90.74 & 7,945 & 38.42 & 33.00 & 20.47 & 1,101 \\
\hline $\begin{array}{l}\text { Origination Amount } \\
\text { Squared }\end{array}$ & 26,463 & 12,210 & 41,150 & 9,046 & 29,868 & 15,575 & 42,802 & 7,945 & 1,894 & 1,089 & 2,418 & 1,101 \\
\hline CLTV* & 78 & 80 & 16 & 9,046 & 75 & 80 & 15 & 7,945 & 96 & 100 & 10 & 1,101 \\
\hline $\mathrm{FICO}$ & 576.6 & 583 & 31.218 & 9,046 & 574.661 & 580 & 31.613 & 7,945 & 590.7 & 596 & 23.850 & 1,101 \\
\hline Refinance - No Cash & 0.14 & 0 & 0.346 & 9,046 & 0.152 & 0 & 0.359 & 7,945 & 0.047 & 0 & 0.212 & 1,101 \\
\hline Refinance - Cash Out & 0.693 & 1 & 0.461 & 9,046 & 0.749 & 1 & 0.434 & 7,945 & 0.292 & 0 & 0.455 & 1,101 \\
\hline Low Documentation & 0.183 & 0 & 0.387 & 9,046 & 0.2 & 0 & 0.4 & 7,945 & 0.061 & 0 & 0.239 & 1,101 \\
\hline No Documentation & 0.005 & 0 & 0.072 & 9,046 & 0.005 & 0 & 0.073 & 7,945 & 0.004 & 0 & 0.06 & 1,101 \\
\hline 15 Year Term & 0.109 & 0 & 0.312 & 9,046 & 0.092 & 0 & 0.289 & 7,945 & 0.233 & 0 & 0.423 & 1,101 \\
\hline 20 Year Term & 0.12 & 0 & 0.325 & 9,046 & 0.054 & 0 & 0.226 & 7,945 & 0.597 & 1 & 0.491 & 1,101 \\
\hline Senior has Juniors & 0.013 & 0 & 0.115 & 9,046 & 0.015 & 0 & 0.123 & 7,945 & 0 & 0 & 0 & 1,101 \\
\hline Subordinate Lien & 0.122 & 0 & 0.327 & 9,046 & 0 & 0 & 0 & 7,945 & 1 & 1 & 0 & 1,101 \\
\hline
\end{tabular}

Owner Occupied FRM loans originated during June 2003 from the LoanPerformance (LP) databases. Loans with buy down or IO provisions are excluded along with loans with FICO scores under 500. We include only purchase and refinance loans on 1-4 family homes with term lengths of 15,20 or 30 years. Only loans in Metropolitan Statistical Areas (MSAs) with at least 5 observations are included. Payoff is defined as voluntary prepayment (foreclosures are excluded). Housing price growth is calculated using OFHEO MSA.

"The CLTV for senior (first) liens refers to the LTV of just the first lien due to data limitations. The CLTV is used for Junior Liens. 
Table 6: OLS of mortgage coupon on prepayment penalty for subprime loans

\begin{tabular}{|c|c|c|c|}
\hline & All Liens & Senior Liens & Junior Liens \\
\hline Dependent Variable & Coupon Rate & Coupon Rate & Coupon Rate \\
\hline Dependent Variable Mean & 8.363 & 7.956 & 11.304 \\
\hline Prepayment Penalty (d) & $\begin{array}{l}-\mathbf{0 . 1 9 5} \\
(-6.90)\end{array}$ & $\begin{array}{l}-\mathbf{0 . 1 3 9} \\
(-4.55)\end{array}$ & $\begin{array}{l}\mathbf{- 0 . 6 2 4} \\
(-7.93)\end{array}$ \\
\hline FICO & $\begin{array}{l}-0.021 \\
(-1.76)\end{array}$ & $\begin{array}{l}-0.020 \\
(-1.65)\end{array}$ & $\begin{array}{l}0.033 \\
(0.71)\end{array}$ \\
\hline FICO Squared & $\begin{array}{l}0.000 \\
(0.64)\end{array}$ & $\begin{array}{l}0.000 \\
(0.53)\end{array}$ & $\begin{array}{l}-0.000 \\
(-0.93)\end{array}$ \\
\hline Origination Amount & $\begin{array}{c}-0.009 \\
(-22.49)\end{array}$ & $\begin{array}{l}-0.009 \\
(-22.12)\end{array}$ & $\begin{array}{l}-0.010 \\
(-2.12)\end{array}$ \\
\hline Origination Amount Squared & $\begin{array}{c}0.000 \\
(15.42)\end{array}$ & $\begin{array}{c}0.000 \\
(15.32)\end{array}$ & $\begin{array}{l}0.000 \\
(0.71)\end{array}$ \\
\hline CLTV $^{*}$ above 97 (d) & $\begin{array}{l}0.898 \\
(14.79)\end{array}$ & $\begin{array}{c}0.904 \\
(11.01)\end{array}$ & $\begin{array}{l}1.246 \\
(7.82)\end{array}$ \\
\hline CLTV $^{*} 90$ to 97 (d) & $\begin{array}{l}0.720 \\
(21.54)\end{array}$ & $\begin{array}{c}0.667 \\
(19.91)\end{array}$ & $\begin{array}{l}1.445 \\
(8.28)\end{array}$ \\
\hline $\mathrm{CLTV}^{*} 80$ to 90 (d) & $\begin{array}{c}0.316 \\
(12.68)\end{array}$ & $\begin{array}{c}0.312 \\
(12.66)\end{array}$ & $\begin{array}{l}0.309 \\
(1.86)\end{array}$ \\
\hline Refinance No Cash Out (d) & $\begin{array}{l}-0.250 \\
(-5.95)\end{array}$ & $\begin{array}{l}-0.308 \\
(-6.94)\end{array}$ & $\begin{array}{l}0.250 \\
(1.60)\end{array}$ \\
\hline Refinance Cash Out (d) & $\begin{array}{l}-0.153 \\
(-4.40)\end{array}$ & $\begin{array}{l}-0.192 \\
(-5.03)\end{array}$ & $\begin{array}{l}0.052 \\
(0.58)\end{array}$ \\
\hline Low Documentation $\quad$ (d) & $\begin{array}{c}0.436 \\
(16.34)\end{array}$ & $\begin{array}{c}0.437 \\
(16.50)\end{array}$ & $\begin{array}{l}0.258 \\
(1.87)\end{array}$ \\
\hline No Documentation (d) & $\begin{array}{l}0.424 \\
(3.05)\end{array}$ & $\begin{array}{l}0.379 \\
(2.69)\end{array}$ & $\begin{array}{l}0.808 \\
(1.61)\end{array}$ \\
\hline 15 Year Term (d) & $\begin{array}{l}-0.261 \\
(-7.51)\end{array}$ & $\begin{array}{l}-0.251 \\
(-6.77)\end{array}$ & $\begin{array}{l}-0.627 \\
(-5.74)\end{array}$ \\
\hline 20 Year Term (d) & $\begin{array}{l}-0.133 \\
(-3.44)\end{array}$ & $\begin{array}{l}-0.153 \\
(-3.27)\end{array}$ & $\begin{array}{l}-0.525 \\
(-5.22)\end{array}$ \\
\hline Senior has Juniors (d) & $\begin{array}{l}0.067 \\
(0.75)\end{array}$ & $\begin{array}{l}0.005 \\
(0.06)\end{array}$ & \\
\hline Junior Lien (d) & $\begin{array}{c}2.471 \\
(40.37)\end{array}$ & & \\
\hline $\begin{array}{l}\text { MSA Fixed Effects } \\
\text { Count }\end{array}$ & $\begin{array}{c}\text { Yes } \\
9,046\end{array}$ & $\begin{array}{c}\text { Yes } \\
7,945\end{array}$ & $\begin{array}{l}\text { Yes } \\
1,101\end{array}$ \\
\hline
\end{tabular}

Owner Occupied FRM loans originated during June 2003 from the LoanPerformance (LP) databases. Loans with buydown or IO provisions are excluded along with loans with FICO scores under 500. We include only purchase and refinance loans on 1-4 family homes with term lengths of 15, 20 or 30 years. Only loans in Metropolitan Statistical Areas (MSAs) with at least 5 observations are included.

Coefficients reported are from an ordinary least squares linear regression. Dummy (discrete) variables are marked with a (d) after the variable name. T-statistics are in parentheses. 
Figure 1: Mortgage premia and the borrower's net utility gain from homeownership
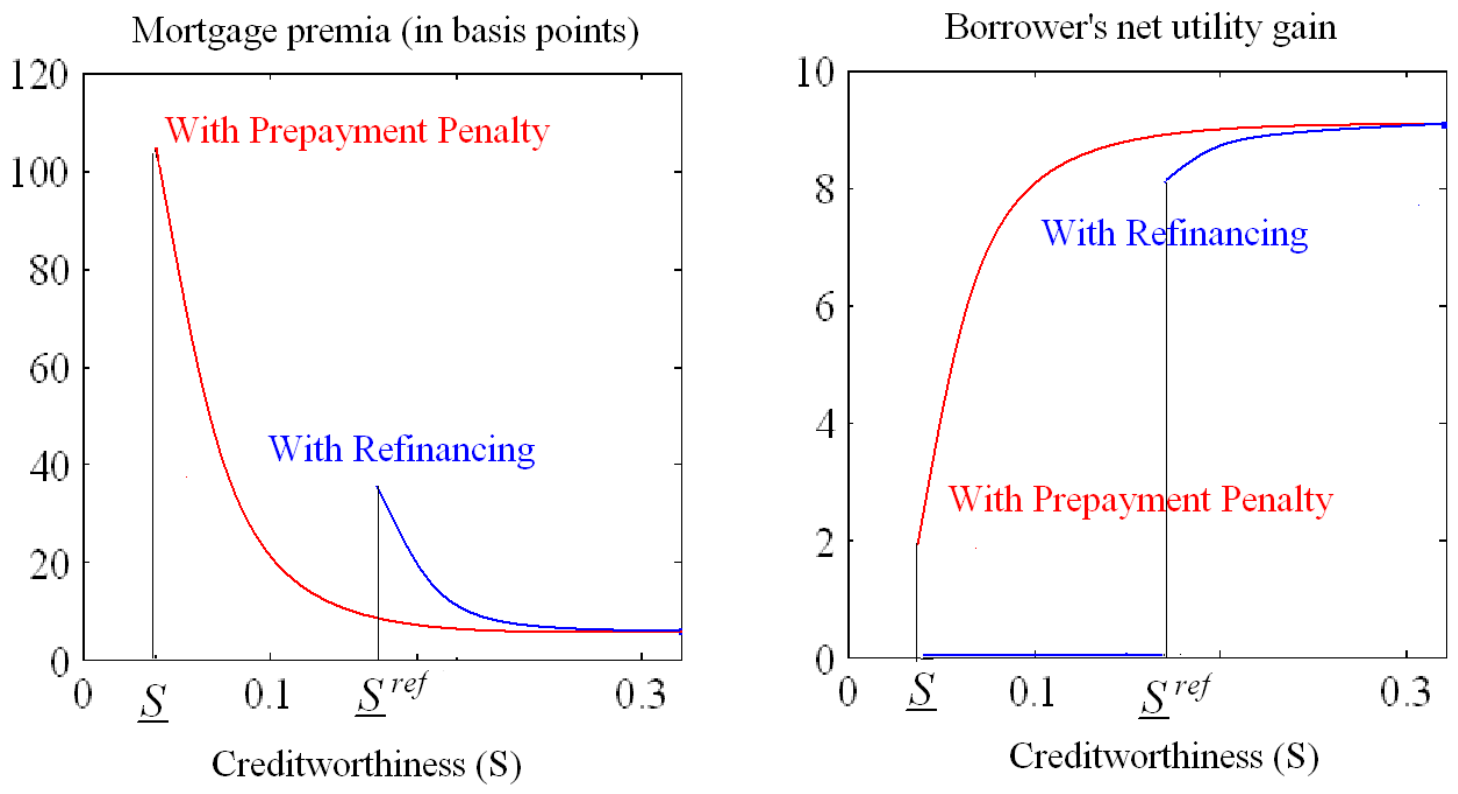
Figure 2: Conventional 30-year FRM rate (Freddie Mac Primary Market Mortgage Survey)

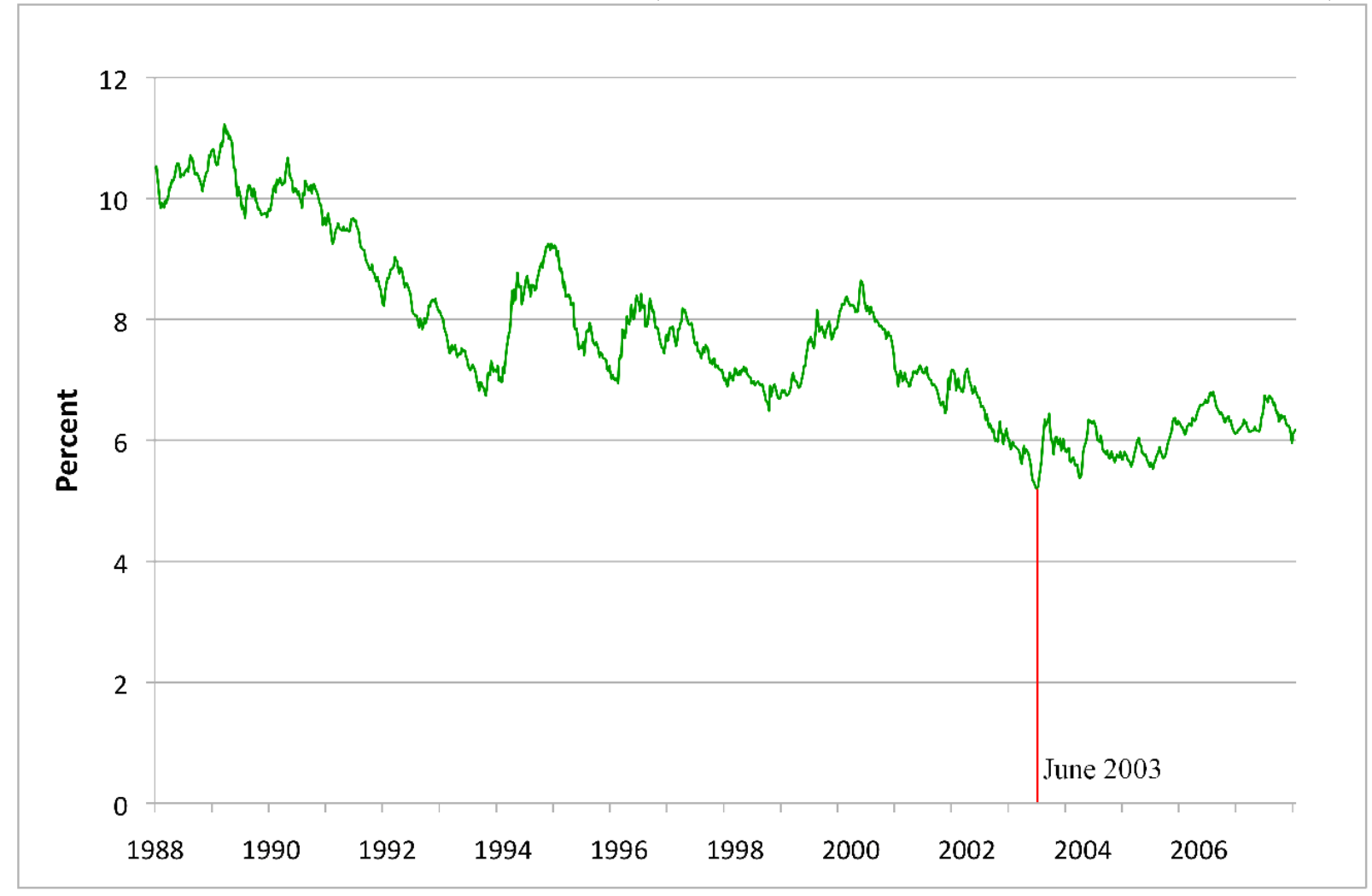


Figure 3: Percentage of loans with prepayment penalties

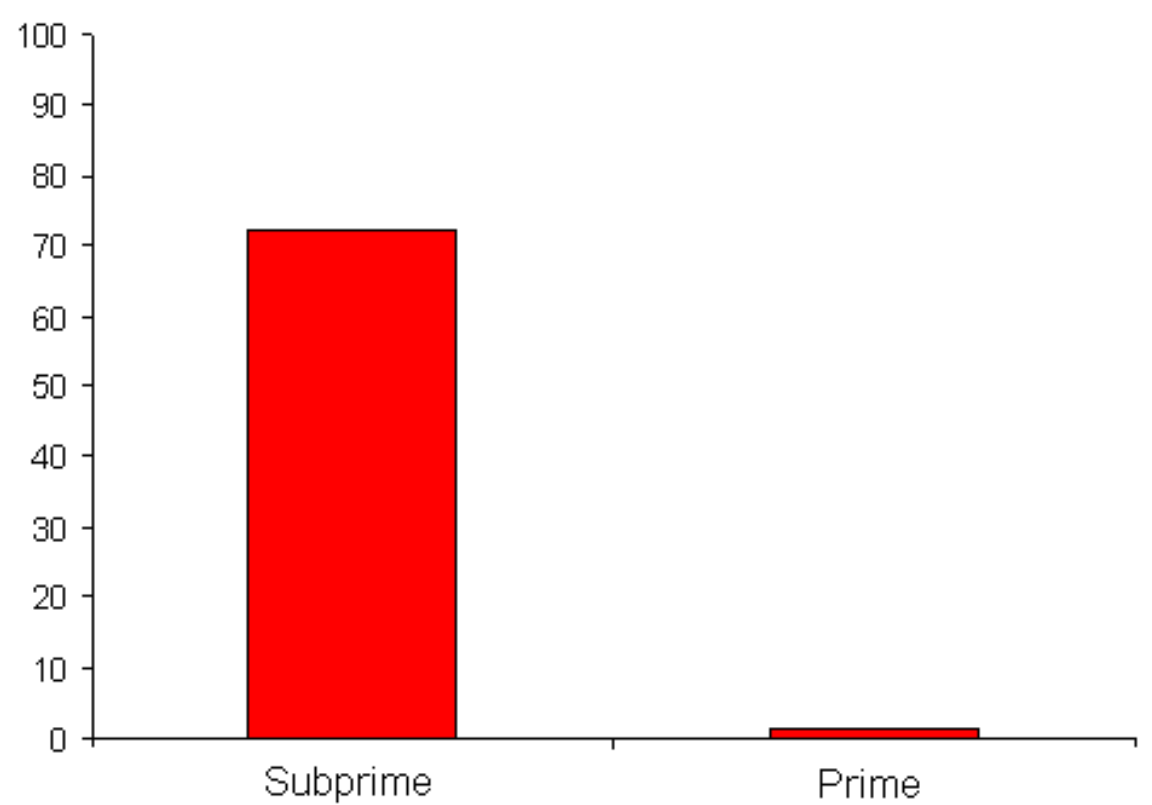

Owner occupied FRM loans originated in June 2003 (LP database) 